\title{
Lessons learned from the past earthquakes on building performance in Turkey
}

\author{
Barbaros Atmaca*iD, Serhat Demir $^{\text {iD }}$, Murat Günaydın ${ }^{\text {iD }}$, Ahmet Can Altunışık

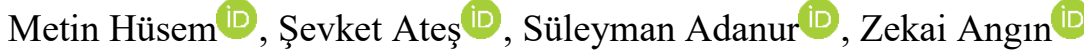 \\ Karadeniz Technical University, Department of Civil Engineering, Trabzon, Turkey
}

\begin{abstract}
In the last 30 years, about twenty earthquakes, which were greater than magnitude $M=6.0$, occurred in different parts of Turkey especially close to fault lines. These earthquakes caused many buildings to be destroyed or heavily damaged, and the loss of many people's lives. The painful lessons learned after the earthquakes resulted to the revision or change of the current earthquake codes used in Turkey for this period. Considering the fault characteristics in Turkey, it is expected to be major earthquakes in the coming years. Lessons learned from the past earthquakes will be very important in reducing the damages that will occur in future earthquakes. When looking into the building stock in Turkey, it is observed that a large part of the housing stock consisting of reinforced concrete (RC) and masonry structures. This paper aims to outline the performance of masonry and RC buildings during the six major catastrophic earthquakes occurred between 1992 and 2020 in various regions of Turkey. Also, a short summary is given about the development of the earthquake codes used in Turkey between 1940 and 2018. The selected six hazardous earthquakes that occurred on the North Anatolian Fault (NAF) and East Anatolian Fault (EAF) are 13 March 1992 Erzincan, 27 June 1998 Adana-Ceyhan, 17 August 1999 Kocaeli, 1 May 2003 Bingöl, 23 October 2011 Van and 24 January 2020 Elazığ-Sivrice earthquakes. At the end of the study, the types of damage occurring in the masonry and RC buildings were given in detail according to years, and the relationship between the changes that occurred in the earthquake codes over time was presented.
\end{abstract}

\section{Keywords}

Building; Damage; Earthquake; Masonry; Reinforced concrete.

Received: 16 April 2020; Accepted: 16 June 2020

ISSN: 2630-5763 (online) (C) 2020 Golden Light Publishing All rights reserved.

\section{Introduction}

Turkey is located at the center of Eurasian, African and Arabian plate boundaries. The movement of these plates causes to occur most of the earthquakes in Turkey. The boundaries of these plates have formed active fault lines, North Anatolian Faults (NAF), East Anatolian Fault (EAF) and West Anatolian Fault (WAF), on Turkey and a large number of earthquakes occurred close to these active fault lines. Over the last 30 years, these faults ruptured periodically and caused about thirty major earthquakes. It is reported that approximately twenty of these earthquakes have the moment magnitude bigger than $M=6.0$. These earthquakes caused many buildings to be destroyed or heavily damaged and enormous loss of life as well as huge economic losses.

* Corresponding author

Email: atmaca@ktu.edu.tr 
The performance of engineering structures exposed to earthquake can be determined better during earthquakes than analytical studies or laboratory tests. Because after the earthquakes, the behavior of different types of structures, damage patterns on structural elements, collapse mechanism and soil response etc. can be easily observed. For this reason, the damages a result of the earthquakes should be carefully examined and interpreted. Experiences taken from the past earthquakes will be important guide in minimizing loss of life and property in the future earthquakes.

The hazardous effects of earthquakes mainly depend on depth, distance, duration, and peak ground velocity and spectral intensities of earthquakes, also soil properties. It is the known that the main reason of the larger number of person who died or injured in earthquakes is structures built by mankind. For this reason, in order to minimize the number of deaths, structures must be resisting the hazardous effects of earthquakes. Especially in the last two decades, thanks to scientific developments on earthquake engineering and observed data after earthquakes, the earthquake codes have been revised and/or evolved by the countries. Similarly, the earthquake codes used in Turkey has been revised or developed many times between 1923 and 2018.

There are many publications in the literature that examine the damages that occur in buildings as a result of past earthquakes in different parts of the world for better understanding of the earthquake behavior of existing structures. Zhao et al. [1] presented a detail report about the destructive earthquake (12 May 2008, Wenchuan) caused $300 \mathrm{~km}$ fault rupture. They investigated the buildings constructed around both sides of the fault. At the end of the study, the reasons of insufficient performance of the buildings were listed as (i) the peak value of the earthquake is higher than the value given at current seismic code, (ii) poor materials and construction quality, (iii) the large number of an unreinforced masonry building, (iv) using high density non-structural elements and (v) large openings at ground floor. Augenti and Parisi [2] analyzed the observed damages on RC building structures after the L'Aquilea-Italy earthquake (March, 2009) and, recommended some revisions for Italian building code. Penna et al. [3] focused on the performances of old (not designed according to the seismic code) and modern (designed according to the seismic code) masonry buildings after Emilia 2012 earthquake. They concluded that masonry building designed according to the seismic code shown a good performance during earthquake even if it is constructed close the epicenter. Sharma et al. [4] presented the characteristics of April 25, 2015 Gorkha earthquake in Nepal and its effects on masonry and RC buildings. They mentioned that approximately 800,000 buildings were damaged due to low material strength, poor construction and detailing quality. Most of damaged buildings were not designed or constructed properly according to the any regulations. Pinilla et al. [5] highlighted that the plastic hinge mechanism did not occur in the beams at most of the RC buildings during the Lorca-Portugal (May, 2011) earthquake. Gautam et al. [6] summarized some important earthquakes that occurred in the world and also Nepal earthquakes that occurred between 1934 and 1988. They focused on the performance of structures during the earthquakes and explained the lessons to be learned to enhance the earthquake performance. Alih and Vafaei [7] presented an analysis about the damages of RC buildings after the Sabah-Malaysia earthquake (June, 2015). The main reasons of the damages were reported as non-ductile detailing, strong-beam weak-column condition, short-column effect, soft and weak floor mechanism, irregularity in plan and elevation, unconfined gable/infill walls, bad workmanship, and low material strength.

In addition to the above studies, there are many studies about the performance evaluation of RC and masonry buildings during earthquakes occurred in Turkey over the last decades in the literature. Bruneau and Saatcioğlu [8] and Sucuoğlu and Erberik [9] investigated the performance of unreinforced masonry buildings during the 1992 Erzincan earthquake. They emphasized that nonductile structures like unreinforced masonry building heavily damaged or collapsed during the earthquake. Hassan and Sözen [10] proposed an 
alternative simplified method for evaluating to seismic performance of RC buildings. The proposed method was tested on damaged buildings after Erzincan earthquake and its applicability was investigated. Adalier and Aydingun [11] examined the damages occurred in RC buildings after the 27 June 1998 Adana-Ceyhan earthquake. They emphasized that a significant part of the damage was due to poor construction quality and design practice. They also stated that the lack of consideration of local soil conditions caused these damages. U.S. Geological Survey (USGS) [12] prepared a report about the 17 August 1999 Kocaeli earthquake. In this report, it was emphasized that observation made immediately after the earthquake ensure the chance to learn lessons for decreasing the hazardous effects of earthquakes in the U.S. Sezen et al. [13] reported their investigations about the RC structures damages occurred during the 17 August 1999 Kocaeli earthquake. Doğangün [14], Kaplan et al. [15] explained the performance of $\mathrm{RC}$ buildings after the Bingöl earthquake (May, 2003) having $5.45 \mathrm{~m} / \mathrm{s}^{2}$ peak ground acceleration and evaluated the deficiencies that caused the damages in detail. Çağatay [16] conducted an observation on the damaged RC structures after 17 August 1999 İzmit and 27 June 1998 Adana-Ceyhan earthquakes. It has been noted that most of the collapses or damages that occur in the buildings after these earthquakes are caused by insufficient concrete quality since sea sand is used. Arslan and Korkmaz [17] focused on the performance of existing RC buildings during the earthquakes between 1992 and 2004. They emphasized that the main reasons of collapses and damages were insufficient structural carrier system and poor material quality. İlki and Celep [18] emphasized that lessons learned from the past hazardous earthquakes occurred in Turkey contributed to improving material and construction quality, the method for designing of structures and seismic codes. Bayraktar et al. [19-20] and Ateş et al. [21] investigated the structural behavior of RC, masonry and adobe buildings in the affected territory around the Van city in Turkey after two devastating earthquakes (23 October 2011 Ercis and 9 November 2011 Edremit earthquakes.

A big part of the building stock of Turkey has formed as RC buildings in urban areas and masonry buildings in rural areas. In these structures, the lessons to be learned from the past earthquakes damages will be very important in reducing the possible future earthquake damages. The aim of this study is to investigate the damages on masonry and RC buildings during the earthquakes occurred between 1992 and 2020 in Turkey. Past earthquake observations and different needs with the development of technologies such as performance analyses, repairing and retrofitting project, design of non-structural structural elements, special rules for cast-in-place and precast carrier systems, mild steel buildings, wooden buildings, tall buildings, seismically isolated buildings and structure-soilpile interaction have led to developments of earthquake code on a large scale. In this context, a brief summary of the revisions and changes that occurred in the earthquake codes is also presented.

\section{Seismicity and occurrence of earthquakes in Turkey}

The seismicity of Turkey is considerably influenced by the motions of the three main plates; Eurasian, Arabian, and African as seen in Fig. 1. Eurasian Plate is comparatively stable according to Arabian and African plates which tended to move northward direction.

The motion of these plates with respect to each other has led to the formation of fault lines in Turkey. Three major fault lines, $1500 \mathrm{~km}$ long North Anatolian Faults (NAF), 550 km long East Anatolian Fault (EAF) and West Anatolian Fault (WAF), run through the Turkey. The ruptures of these faults have caused to occur more than 800 earthquakes with different magnitudes in the last 120 years in Turkey according to data obtained from Earthquake Department of the Disaster and Emergency Management Presidency (AFAD) [22]. When considering the past earthquakes, it can be seen that the earthquakes in Turkey have short return periods. 


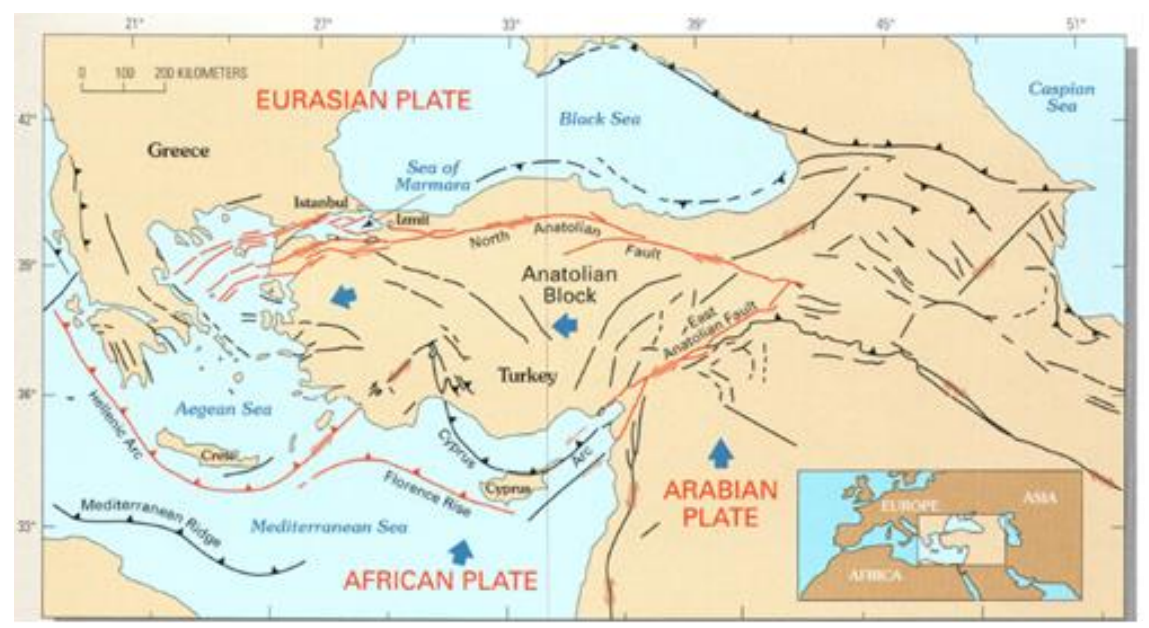

Fig. 1. Tectonic plates and Turkey's location (USGS) [12]

Table 1. Past earthquakes in Turkey and surroundings between 1900 and 2020 [22]

\begin{tabular}{lccc}
\hline Magnitude of earthquake & $6>\mathrm{M}>=5$ & $7>\mathrm{M}>=6$ & $\mathrm{M}>7$ \\
\hline Number of events & 702 & 81 & 17 \\
\hline Return periods (years) & 0.2 & 1.5 & 7 \\
\hline
\end{tabular}

The number of earthquakes and their return periods with different magnitudes that occurred in the last 120 years in Turkey is given in Table 1.

In general, the earthquake with a magnitude between $\mathrm{M}=7.0$ and $\mathrm{M}=7.9$ (caused serious damage) is considered as major earthquake [23]. This type of earthquake causes many buildings to be collapsed or heavily damaged, and the loss of many people's lives. The return period of major earthquakes that occurred in Turkey is seven-year. It is a very short return period for a major earthquake. Earthquakes with magnitude greater than $\mathrm{M}=7.0$ occurred since 1900 in Turkey is shown in Fig. 2.

It is seen that most of these earthquakes occur regions located close to the NAF. Earthquake with magnitude greater than $\mathrm{M}=6.0$ occurred between 1992 and 2020 in Turkey is shown in Fig. 3. When Fig. 3 is examined, it can be seen that the many earthquakes with magnitude greater than $M=6.0$ in last 30 years occurred close to $\mathrm{EAF}$ and WAF rather than NAF.

In this paper, six catastrophic earthquakes occurred between 1992 and 2020 in various regions of Turkey is considered. These earthquakes can be listed as 13 March 1992 Erzincan, 27 June 1998 Adana-Ceyhan, 17 August 1999 Kocaeli, 1 May 2003 Bingöl, 23 October 2011 Van and 24 January 2020 Elazığ-Sivrice earthquakes (Fig. 4).

According to the official reports given by the government, Table 2 summarizes the properties of earthquakes, casualties, number of damaged or collapsed buildings.

Since the establishment of the Republic of Turkey in 1923, several regulations were published by the Disaster and Emergency Management Presidency (DEMP) in order to prevent casualties and financial losses after natural disasters. Design sections for masonry, adobe and RC structures have been detailed and developed in the regulations throughout the time. The first Turkish earthquake code for buildings was published in 1940 after the 1939 Erzincan earthquake $\left(\mathrm{M}_{\mathrm{s}}=7.9\right)$. This earthquake affected the whole country, damaged $1 / 20$ of its total area and caused more than 30,000 people died. In this context, a brief summary about the changes in the Turkish earthquake codes between 1940 and 2018 is given in Table 3 . 


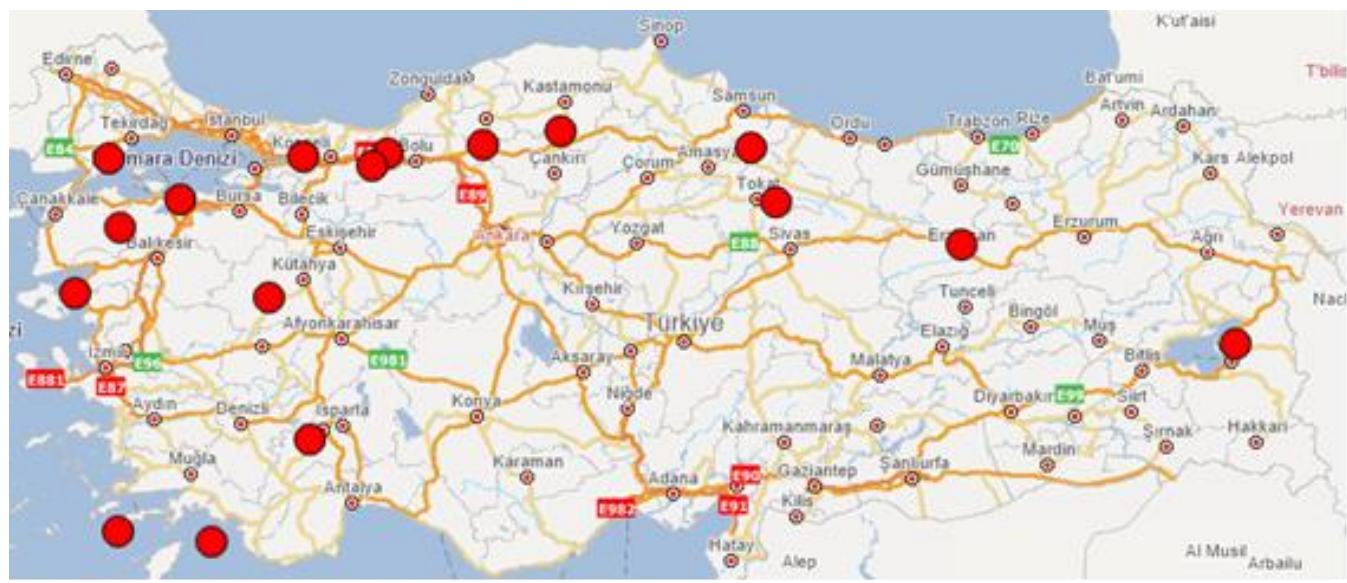

Fig. 2. Historical earthquakes with magnitude $M=7.0$ and greater since 1900 [22]

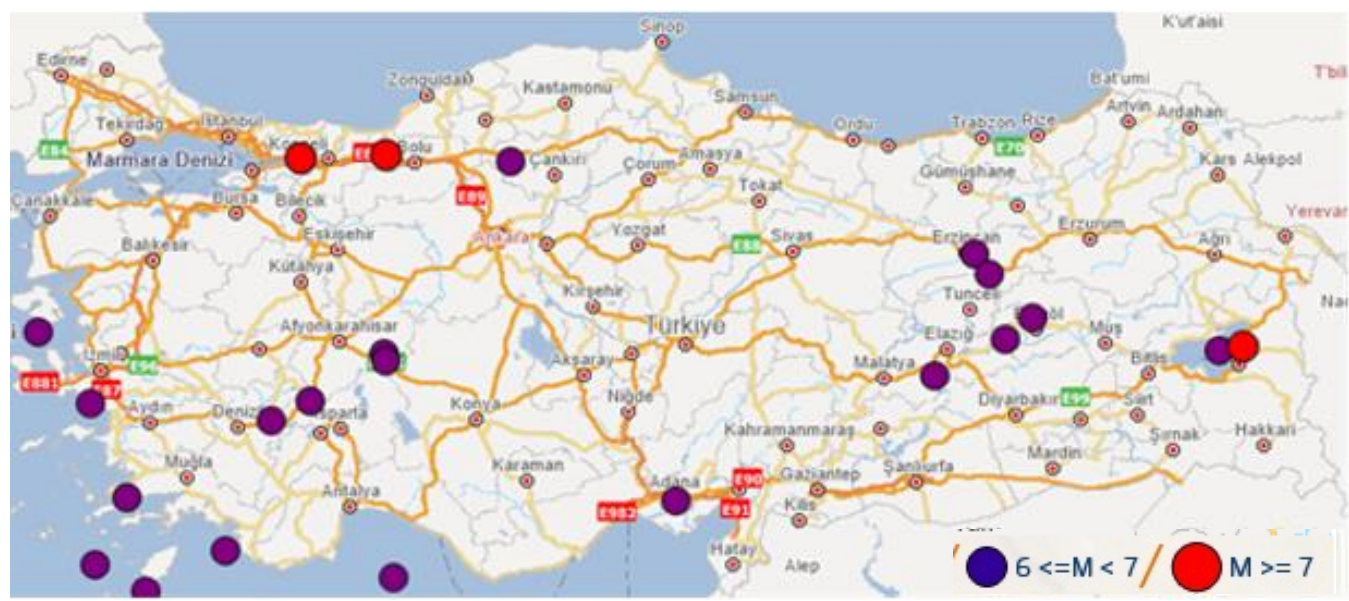

Fig. 3. Historical earthquakes with magnitude $M=6.0$ and greater since 1992 [22]

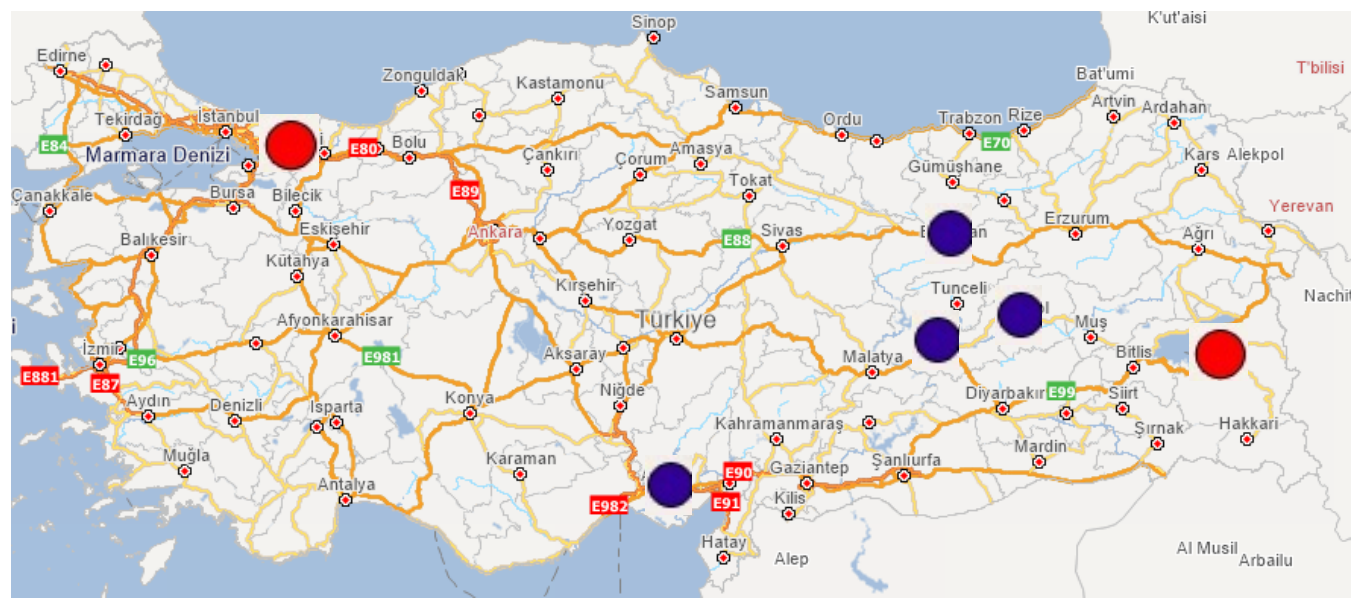

Fig. 4. The location of the selected earthquakes in this study [22] 
Table 2. Some information about selected earthquakes [22]

\begin{tabular}{|c|c|c|c|c|c|}
\hline Date & Region & $\begin{array}{l}\text { Depth } \\
(\mathrm{km})\end{array}$ & $\begin{array}{l}\text { Magnitude } \\
\qquad\left(\mathrm{M}_{\mathrm{w}}\right)\end{array}$ & Casualties & $\begin{array}{l}\text { Damaged or } \\
\text { Collapsed Buildings }\end{array}$ \\
\hline 13 March 1992 & Erzincan & 29 & 6.6 & 653 (Died) & 6702 \\
\hline 27 June 1998 & Adana-Ceyhan & 23 & 6.2 & $\begin{array}{l}145 \text { (Died) } \\
1500 \text { (Injured) }\end{array}$ & No records available \\
\hline 17 August 1999 & Kocaeli & 17 & 7.6 & $\begin{array}{l}18,373 \text { (Died) } \\
24,286 \text { (Injured) }\end{array}$ & More than 150,000 \\
\hline 1 May 2003 & Bingöl & 10 & 6.4 & $\begin{array}{l}176 \text { (Died) } \\
520 \text { (Injured) }\end{array}$ & 625 \\
\hline 23 October 2011 & Van & 16 & 7.1 & $\begin{array}{l}644 \text { (Died) } \\
1966 \text { (Injured) }\end{array}$ & 2262 \\
\hline 24 January 2020 & Elazı ̆̆-Sivrice & 31 & 6.2 & $\begin{array}{l}\text { 41(Died) } \\
\text { 1607(Injured) }\end{array}$ & 584 \\
\hline
\end{tabular}

Table 3. The development of Turkish earthquake codes between 1940 and 2018

The first Turkish seismic design code for buildings was published in 1940 (TEC 1940) [24]

\begin{tabular}{lll}
\hline & - New seismic zone maps was prepared $(1942,1945,1963)$ \\
Important & - The procedure for calculating the lateral force coefficient was changed in 1961 \\
events between & - & 1942 Tokat-Erbaa earthquake $\left(\mathrm{M}_{\mathrm{s}}=7.0\right), 1944$ Bolu-Gerede earthquake $\left(\mathrm{M}_{\mathrm{s}}=7.2\right)$, \\
$1940-1968$ & 1953 Çanakkale-Yenice earthquake $\left(\mathrm{M}_{\mathrm{s}}=7.2\right), 1957$ Muğla-Fetihe earthquake $\left(\mathrm{M}_{\mathrm{w}}=\right.$ \\
& $\begin{array}{l}7.1), 1964 \text { Balıkesir-Manyas earthquake }\left(\mathrm{M}_{\mathrm{s}}=7.0\right), 1967 \text { Bolu-Mudurnu earthquake } \\
\left(\mathrm{M}_{\mathrm{s}}=7.2\right)\end{array}$ \\
\hline
\end{tabular}

The second Turkish seismic design code for buildings was published in 1968 (TEC 1968) [25]

- $\quad$ Procedures for calculation of earthquake loads

- Building importance factor were determined

New rules in this code

- Concepts relating to spectral shape and dynamic response.

- The uniform load distribution method suggested in the earlier code was modified with inverted triangle load distribution method.

- Requirement for minimum cross sectional dimensions of column and beam were determined as $24 \times 24 \mathrm{~cm}$ and $15 \times 30 \mathrm{~cm}$, respectively.

The third Turkish seismic design code for buildings was published in 1975 (TEC 1975) [26]

- The concept of ductility was first time mentioned

- Type of the frame system, importance factor, spectral coefficient and seismic map (1972) were taken into consideration for lateral load coefficient calculation.

- Requirement for minimum cross sectional dimensions of column and beam in the earlier

New rules in this code code were modified as $25 \times 25 \mathrm{~cm}$ and $20 \times 30 \mathrm{~cm}$, respectively.

- Minimum concrete strength $18 \mathrm{MPa}$ was determined to be used in seismic zones.

- Significant detailing requirements like maximum transverse reinforcement spacing, confinement regions at each end, middle region and beam column joints regions were defined for beams and columns.

- 135-degree hooks were required for transverse reinforcements at confinement zone. 
Table 3 Cont'd

The fourth Turkish seismic design code for buildings was published in 1998 (TEC 1998) [27]
- $\begin{aligned} & \text { The mode superposition method, linear and nonlinear dynamic analyses were introduced } \\ & \text { Reinforced concrete buildings were categorized as high or nominal ductility based on } \\ & \text { the detailing of structural elements. }\end{aligned}$
- Strong column weak beam concept was included and more stringent detailing
requirements were defined for high ductility systems.
this code
- $\begin{aligned} & \text { Requirement of minimum cross sectional dimensions for column and beam in the earlier } \\ & \text { code were modified as 25x30cm and 25x30cm, respectively. } \\ & \text { - }\end{aligned}$
Minimum concrete strength was defined as C20 (compressive strength is equal to
20MPa) for first and second-degree seismic zones
The usage of ribbed reinforcement steel was made obligatory.

The fifth Turkish seismic design code for buildings was published in 2007 (TEC 2007) [28]

- New section about the evaluation and retrofitting of existing structures named as

New rules in this code performance analyses were added.

- $\quad$ Pushover and capacity spectrum procedures were introduced.

- $\quad$ Minimum concrete strength was defined as C20 for all seismic zones

The sixth Turkish seismic design code for buildings was published in 2018 (TEC 2018) [29]

- Turkey's seismic hazard map was updated

- The site specific earthquake hazard definition and deformation-based design procedure was improved

- New sections were added about the design of non-structural structural elements, special

New rules in this code rules for the design of cast-in-place and precast reinforced concrete building carrier systems, earthquake design of mild steel buildings, wooden buildings, tall buildings, seismic isolated buildings, and structural modelling rules for piled foundations.

- Minimum concrete strength increased to C25 (compressive strength is equal to 25MPa) to be used in all seismic zones.

- Requirement of minimum cross sectional dimensions for columns in the earlier code was modified as $30 \times 30 \mathrm{~cm}$.

Similar to the Turkish earthquake code, seismic zone map of Turkey developed throughout the time thanks to improving in earthquake engineering and statistical methods, increasing of collected data about properties of past earthquakes.

Fig. 5 present the past seismic zoning maps used in 1972 and 1996, also Turkey's new earthquake hazard map in 2018. According to the seismic zoning map used in 1972 and 1996, the whole country is divided into five zones. Newlyintroduced "Turkey Earthquake Hazard Map" came into force on 1 January 2019. Unlike the previous map, the largest map spectral acceleration values (PGA) are presented instead of the earthquake zones.

\section{Damages of building during the past earthquakes}

Turkey is located on a active seismic zone and experienced painfully after many hazardous earthquakes throughout the last century. These earthquakes caused many buildings to be destroyed or heavily damaged, and enormous loss of life as well as huge economic losses. Experiences taken from the past earthquakes will be important guide in minimizing loss of life and property in the future earthquakes. Especially in the last two decades, thanks to observed data after earthquakes and scientific developments on earthquake engineering and seismology, the earthquake codes and seismic zoning maps have been revised and/or evolved by the countries. 
(a)

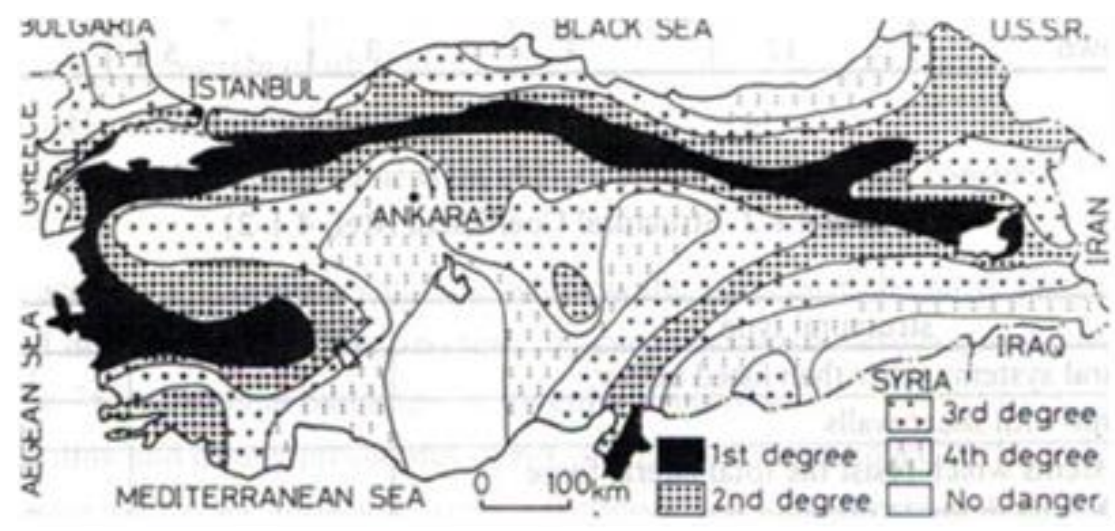

(b)

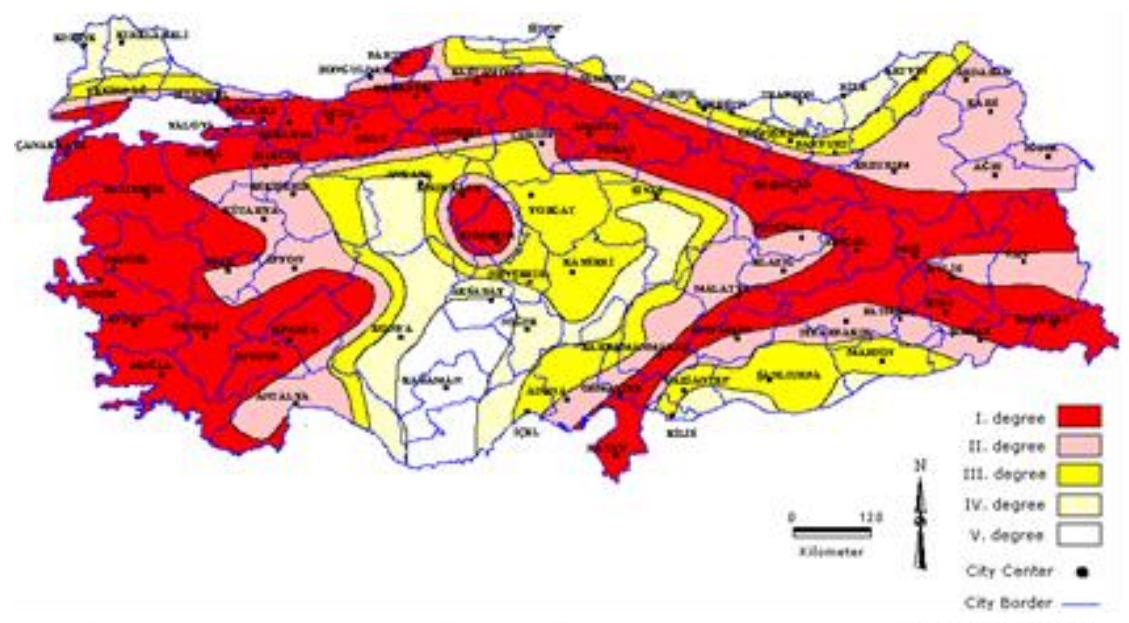

(c)

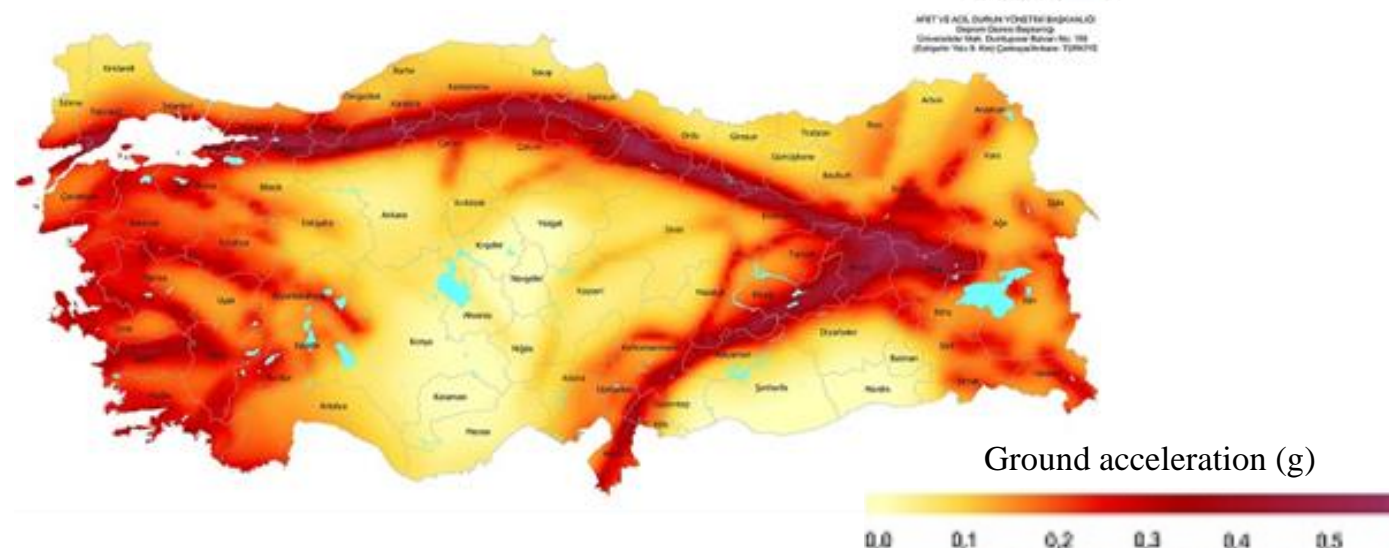

Fig. 5. Past seismic zone map used (a) in 1972 [30], (b) in 1996, (c) Turkey's new earthquake hazard map 2018

The large number part of the housing stock consists of RC and masonry structures in Turkey. These types of buildings have seriously affected from past earthquakes. This paper aims to outline the performance of masonry and RC buildings during the six major catastrophic earthquakes occurred between 1992 and 2020 in various regions of Turkey. The selected six hazardous earthquakes that occurred on the North Anatolian Fault (NAF) and East Anatolian Fault (EAF) are 13 March 1992 Erzincan, 27 June 1998 Adana-Ceyhan, 17 August 1999 Kocaeli, 1 May 2003 Bingöl, 23 October 2011 Van and 24 January 2020 Elazı $\breve{g}$-Sivrice earthquakes. 


\subsection{Damages of RC buildings}

A considerable percentage of the buildings such as residential, hospital, school etc. were constructed as RC moment-resisting frame buildings especially in the urban areas in Turkey. These types of buildings generally consist of a general type of columns, beams and slabs. Weaknesses in these buildings caused by errors made during design or construction stages have caused damages or collapses. Based on the on-site field investigation conducted after Sivrice-Elazığ earthquake on January 24, 2020, and a literature survey on past earthquakes, the main errors made during design and construction stages caused damage or collapse on RC buildings are given in Table 4 .

\subsubsection{The main errors made during design stages}

Past earthquakes showed that many RC structures damaged or collapsed because of errors made during design stages such as (i) improper selection of the structural system, (ii) irregularities, (iii) strong beam-weak column, (iv) short column, (v) insufficient transverse reinforcement, (vi) soft and weak storey, (vii) existence of short unconfined lap splices, (viii) incorrect end hook angle, (ix) weak walls, (x) hammering effect, (xi) column-beam connection failures, (x) inadequate safe distance. The selection of the structural systems is one of the most important steps. The selection of regular and symmetrical structural system ensures that the applied lateral and vertical loads are transferred to the ground in the shortest way. In addition, the structural elements in a symmetrical system should be continuous. On the other hand, symmetry in the plan will ensure that the rigidity and mass center of the structure approach each other as much as possible, thus reducing the torsion moments that will occur in the building during the earthquake.

\subsubsection{Strong beam-weak column}

The experience taken from the past earthquakes is showed that the reason of the most damages or collapses of RC frame buildings is strong beamweak column mechanism. In this mechanism, plastic hinge occurs on weaker columns, and this event causes unwanted brittle collapsed. But, it is desirable that plastic hinge should be formed in beams rather than columns, thus preventing of brittle collapse. The collapses and damages caused by this mechanism in past earthquakes are shown in Fig. 6. In light of experiences from past earthquakes, strong column-weak beam concept was included in the TEC 1998 and more stringent detailing requirements were defined for high ductility systems.

Table.4. The main errors made during design and construction stages

\begin{tabular}{ll}
\hline Design stages & Construction stages \\
\hline Improper selection of the structural system & Poor concrete quality \\
Irregularities & Unribbed reinforcing bar and corrosion \\
Strong beam-weak column & Incorrect placing of reinforcement bar \\
Short column & Incorrect end hook angle and length \\
Insufficient transverse reinforcement & Weak gable walls \\
Soft and weak storey & Workmanship defects \\
Existence of short unconfined lap splices & \\
Incorrect end hook angle & \\
Weak walls & \\
Hammering effect & \\
Column-beam connection failures & \\
Inadequate safe distance &
\end{tabular}



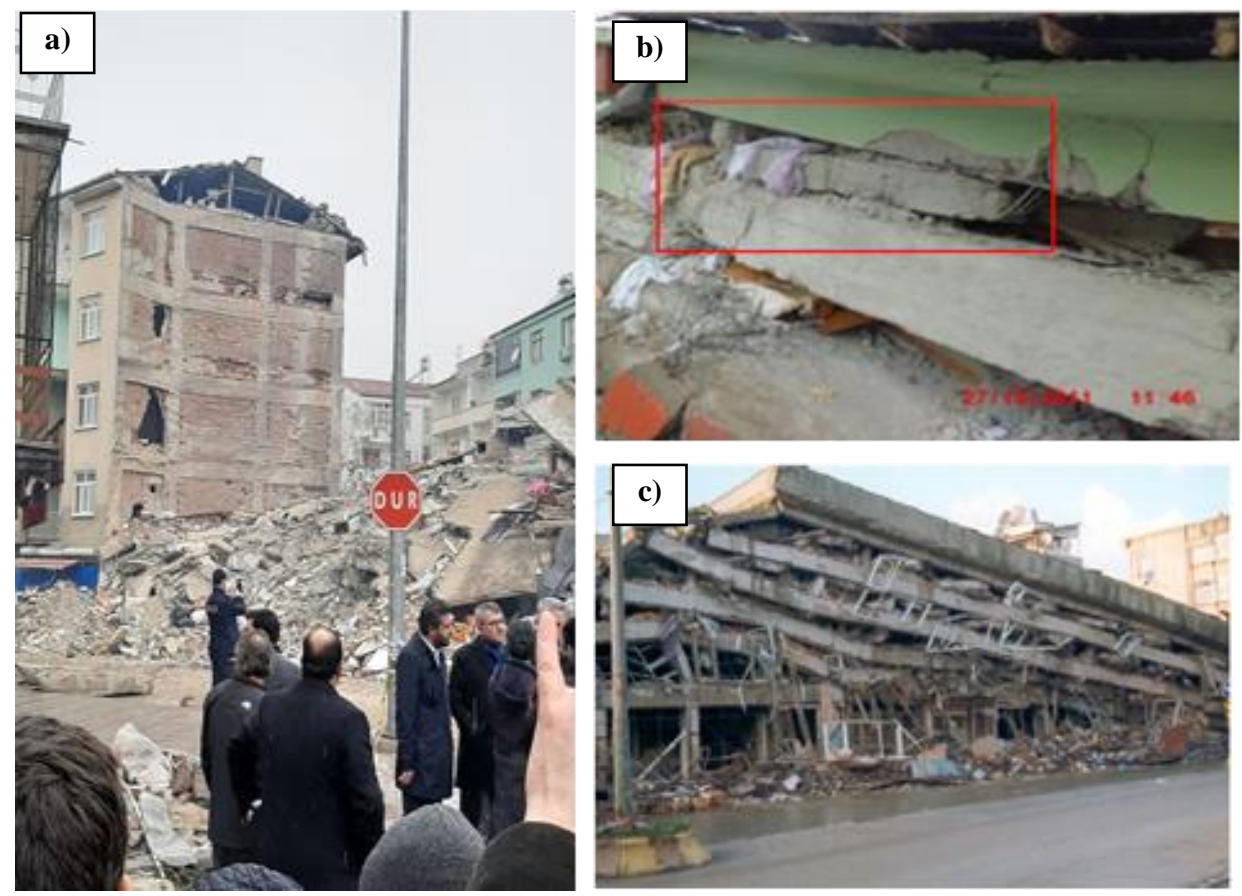

Fig. 6. Strong beam-weak columns damages observed after

(a) Elazığ-Sivrice, (b) Van [21] and (c) Kocaeli [17] earthquakes

\subsubsection{Short column}

Horizontal forces acting on the structure at the floor level during the earthquake are transferred from slabs and beams to columns. These forces cause to be formed bending moments and shear forces into the columns. On account of the arrangement of nonstructural and structural elements such as infill walls with opening and columns, short columns may occur. This causes the column length to be shortened. The shortening of the column length causes the bending moments and shear forces to increase. Past earthquakes showed that short column effect has caused many RC buildings to damage or collapse (Fig. 7)

\subsubsection{Soft storey}

Especially the first floors of many buildings on the main street are used as a commercial area such as shops or showrooms. More than one side of these commercial floors is covered with windows and the second floor is generally closed with infill walls so soft storey problem occurred. In buildings with soft floors, plastic hinges occur in columns and this event causes unwanted brittle collapsed (Fig. 8).

\subsubsection{Hammering effects}

During the earthquake, there must be a sufficient distance between neighboring buildings so that the buildings can move freely and do not have hammering. When the floor levels of the buildings are not equal, they suffer much damage. Although there is a restriction in the the TEC about the minimum safe distance between the adjacent buildings, a significant portion of the building stock in Turkey was built as adjacent. In this case, although the building is not damaged by the earthquake, it increases the probability of damage due to the impact of the neighboring building. The collapses and damages caused by hammering effects in past earthquakes are shown in Fig. 9.

\subsubsection{Existence of short and unconfined lap splices}

Past earthquakes happened in Turkey showed that another significant problem caused to collapse and damage of RC frame buildings was the existence of short and unconfined lap splices. 

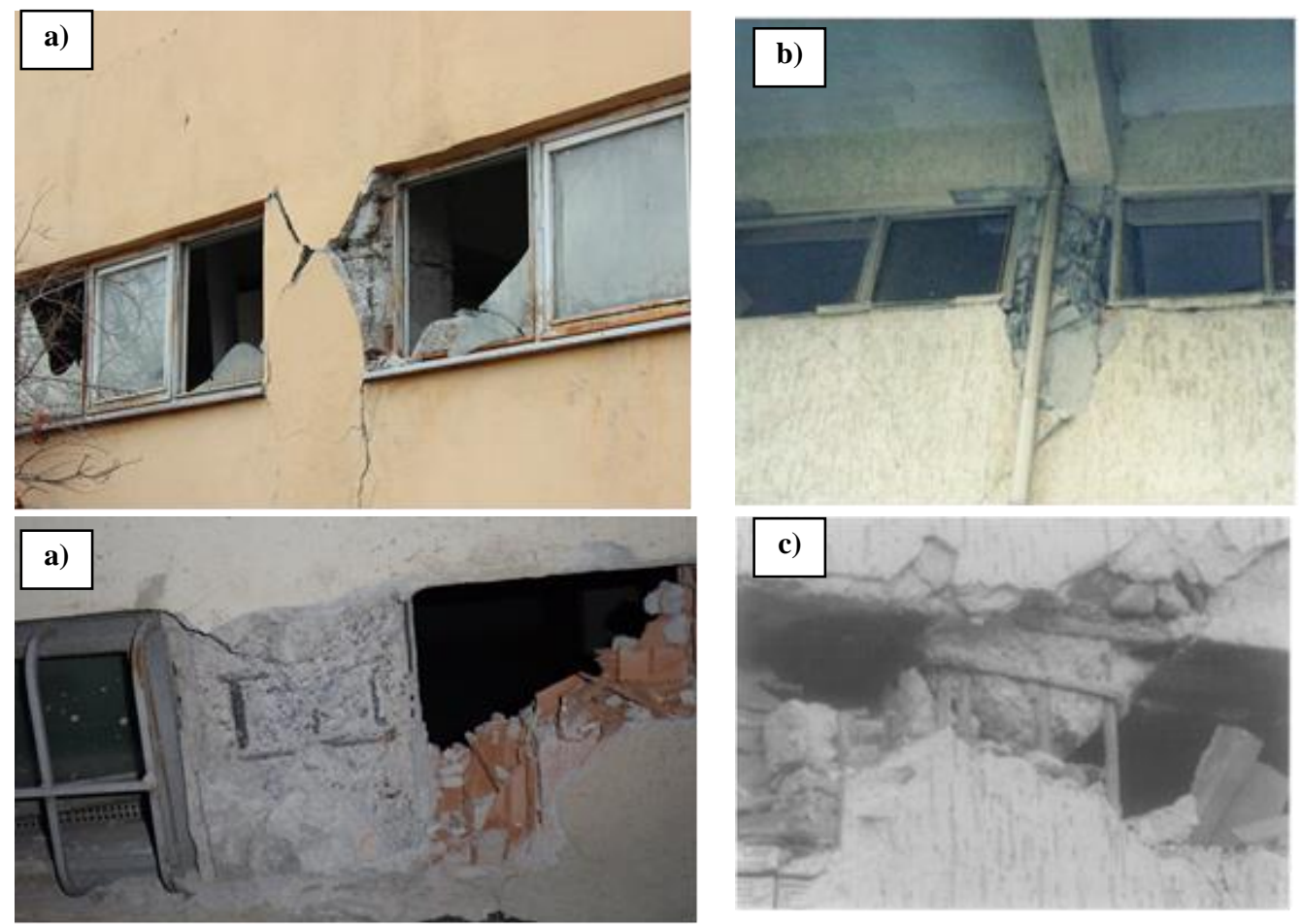

Fig. 7. Short column based damages observed after (a) Elazığ-Sivrice, (b) Kocaeli [17] and (c) Bingö1 [15] earthquakes
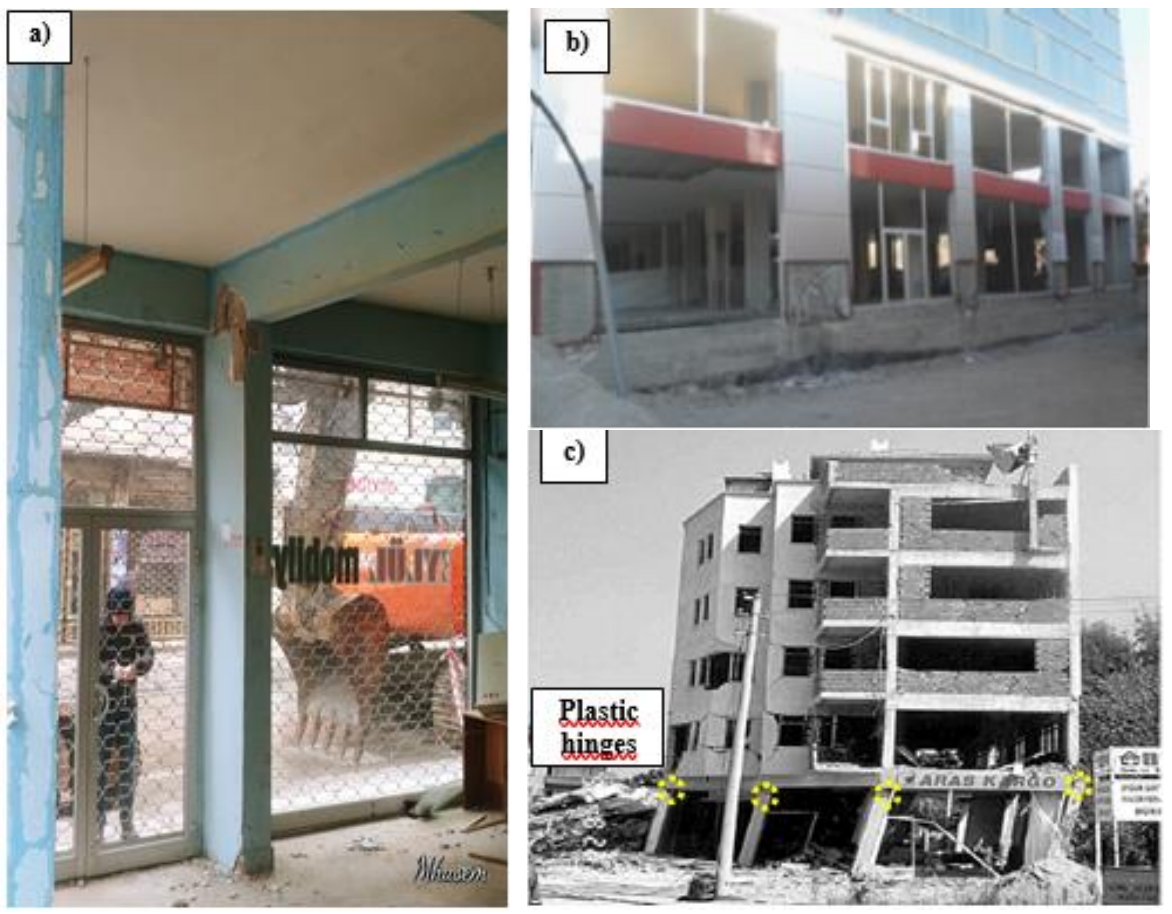

Fig. 8. Soft storey damages observed after

(a) Elazı̆̆-Sivrice, (b) Van [19] and (c) Kocaeli [13] earthquakes 

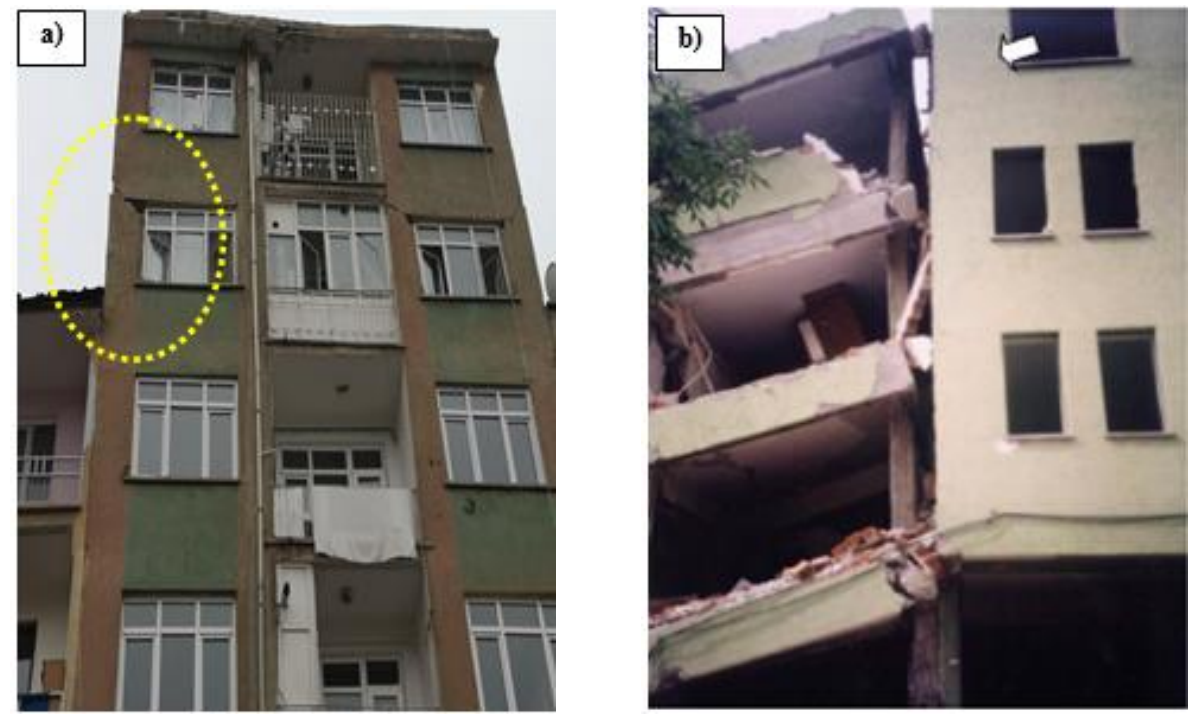

Fig. 9. Observed hammering effects (a) Elazığ-Sivrice and (b) Bingöl [14] earthquakes

According to the TEC 2018, it is mandatory that the lap splice of the column's longitudinal rebar be made in the middle third of the free height of the column for high ductility level column. Some views of the lap splice errors observed after the past earthquake are given in Fig. 10.

\subsubsection{Insufficient transverse reinforcement}

The main functions of the transverse reinforcement in the RC structural elements are to prevent buckling of longitudinal reinforcement, increase the ductility of core concrete and resist the shear force. To prevent these failures, detailing and spacing restrictions given in the regulations must be followed. Two special zones such as confinement and central zone were defined for transverse reinforcement requirements for columns and beams in the TEC after 1975. However, observations made after the earthquakes were showed that these requirements did not considered to some of the damaged or collapsed reinforced concrete buildings (Fig. 11).

\subsubsection{Column-beam connection failures}

In order to ensure sufficient rigidity on the columnbeam connections, these connections should be confined with sufficient stirrup. Sufficient stirrup prevent shear failure of beam-column joints. The collapses and damages caused by column-beam connection failures in past earthquakes are shown in Fig. 12.

\subsubsection{The main errors made during construction stages}

\subsubsection{Poor concrete quality}

The structural performance of RC buildings largely depends on the quality of concrete. In this context, minimum concrete quality has been determined for RC buildings in the past codes. According to the TEC 1975 and the TEC 1998, minimum characteristic strength of the concrete was suggested as $18 \mathrm{MPa}$ and $20 \mathrm{MPa}$, but according to the TEC 2007 and the TEC 2018, minimum characteristic strength of the concrete was raised to $20 \mathrm{MPa}$ and $25 \mathrm{MPa}$, respectively. Although the regulations imposed restrictions on the quality of concrete, it has observed that the concrete quality of the damaged or collapsed buildings in past earthquakes was well below these limits. In addition, it has been observed that inappropriate size distributions and weak round aggregates contain clay and silt was used in concrete manufacturing [14-16, 21]. Fig. 13 display the some photos related to poor concrete quality determined in damaged or collapsed RC buildings in past earthquakes. 

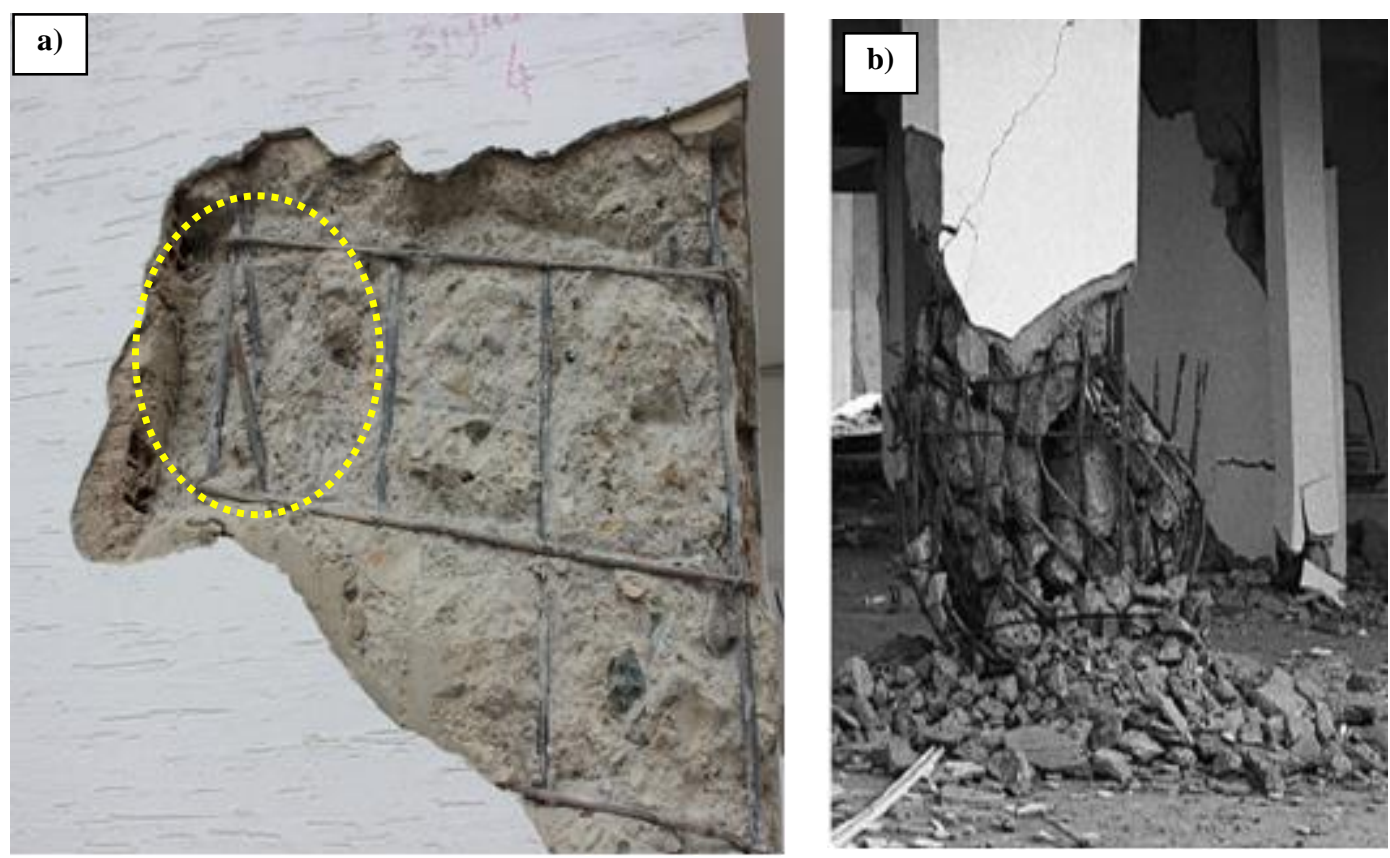

Fig. 10. Observed lap splice errors (a) Elazığ-Sivrice and (b) Kocaeli [13] earthquakes
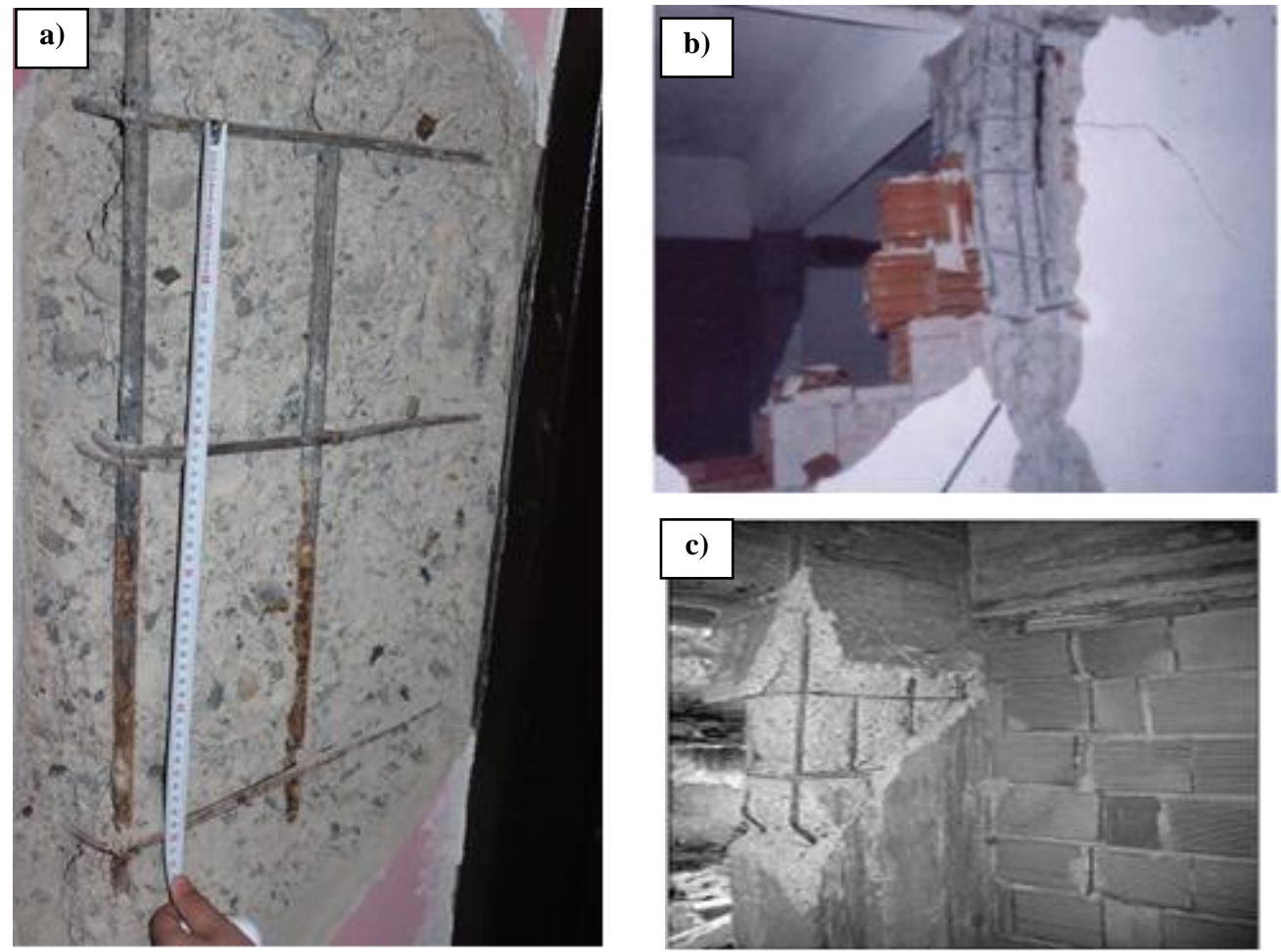

Fig. 11. Insufficient transverse reinforcement damages observed after

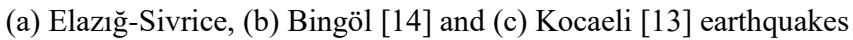



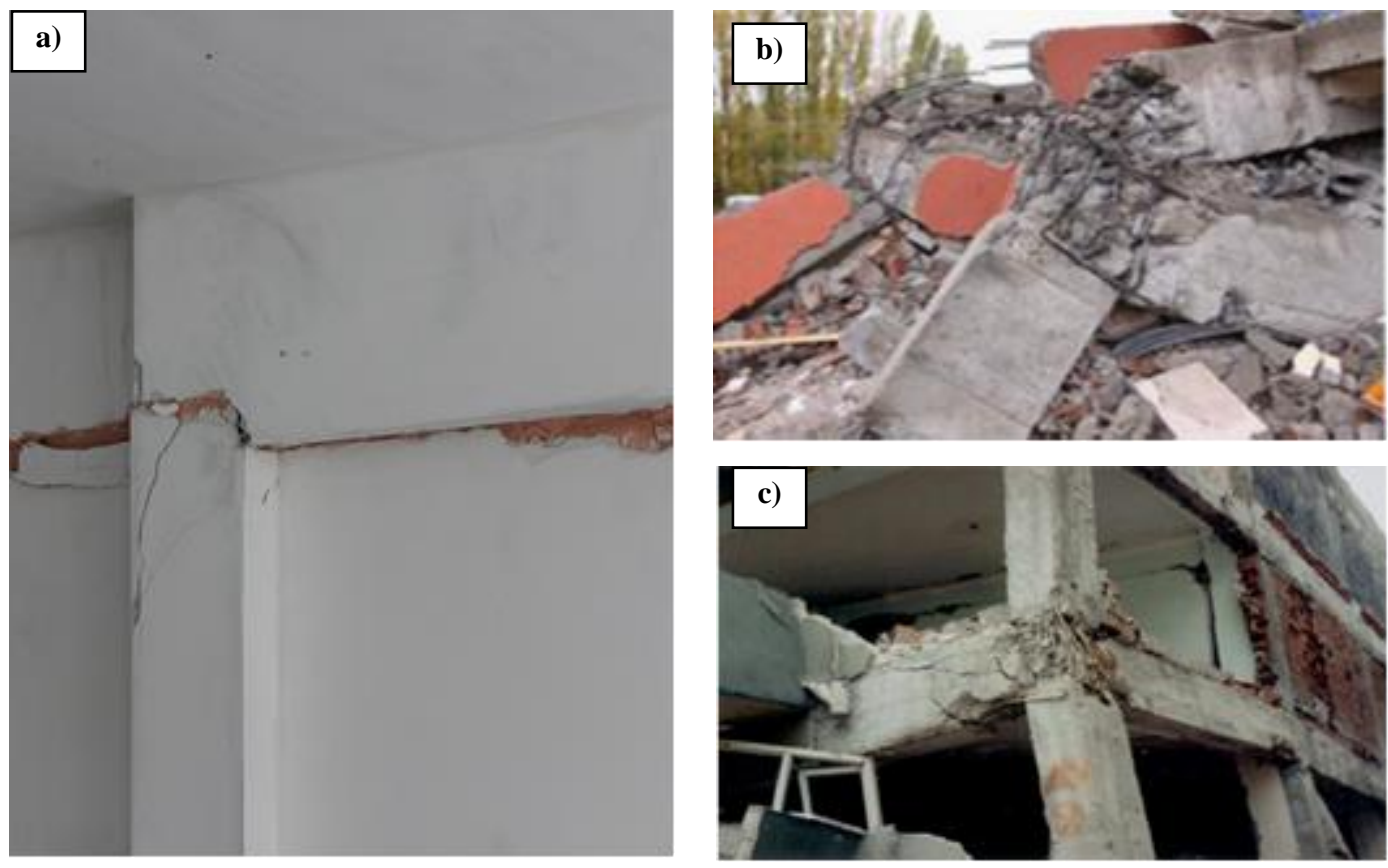

Fig. 12. Column-beam connection failure damages observed after (a) Elazığ-Sivrice, (b) Van [21], and (c) Kocaeli [13] earthquakes
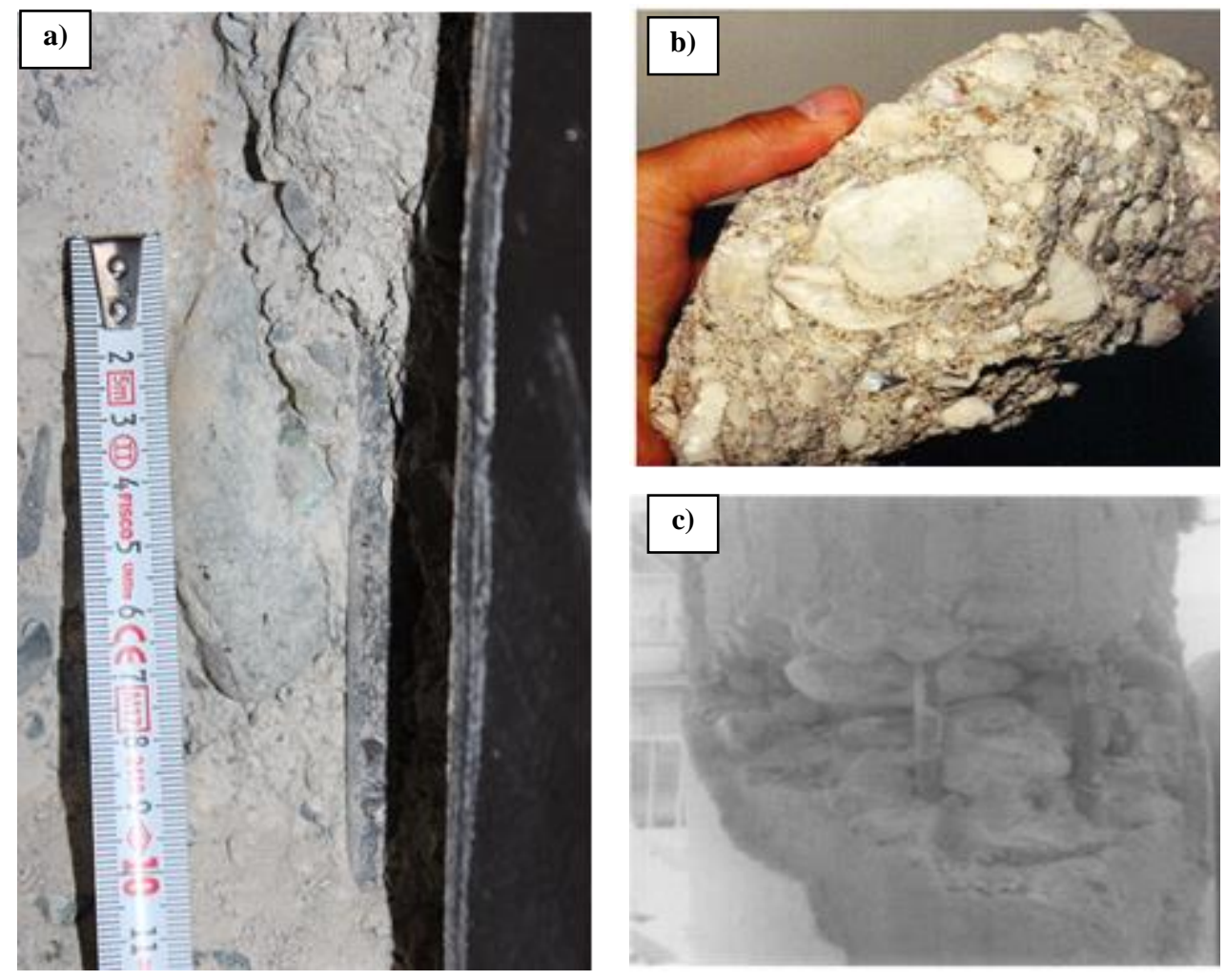

Fig. 13. Poor concrete quality observed after (a) Elazığ-Sivrice (b) Kocaeli [16] and (c) Bingöl [15] earthquake 


\subsubsection{Unribbed reinforcing bar and corrosion}

The usage of the unribbed reinforcement steel had been allowed in the TEC 1975, but the usage of ribbed reinforcement steel was made obligatory in the TEC 1998. Unribbed reinforcement steel having $220 \mathrm{MPa}$ yield strength, and a combination of unribbed reinforced steel with the poor quality concrete cause weaker bond. The use of unribbed reinforcing bar in damaged or collapsed RC buildings in past earthquakes is shown in Fig. 14. Poor concrete quality, insufficient concrete cover and the absence of waterproofing at the basements increase permeability and this is concluded with the corrosion of the reinforcement steel. Corrosion causes to decrease the cross-section area of the reinforcement bar and the weaker bond between the concrete and reinforcement steel. Observed reinforcement steel corrosion in damaged or collapsed RC buildings in past earthquakes is shown in Fig. 14.

\subsubsection{Incorrect placing of reinforcement bar}

One of the most important parameters to affect the performance of RC buildings is the placement of reinforcement bars. Therefore, special attention should be given to the design and application of the transverse and longitudinal reinforcement of structural elements such as beam and column. Past earthquakes showed that a lot of RC buildings collapsed or damaged because of incorrect placing of reinforcement bars (Fig. 15).

\subsubsection{Incorrect end hook angle and length}

It is stated in the TEC 1975 that "end hook angles of the transverse reinforcements must be $135^{\circ}$ in the confinement region, and can be $90^{\circ}$ or $135^{\circ}$ in the middle region. Also, length of the end hook must be 10 times the reinforcement bar". However, previous observations show that end hook angles were $90^{\circ}$ and hook lengths were insufficient (Fig. 16). The transverse reinforcements of the columns and beams that did not have the correct hook angles and lengths were opened up during the earthquake excitation.
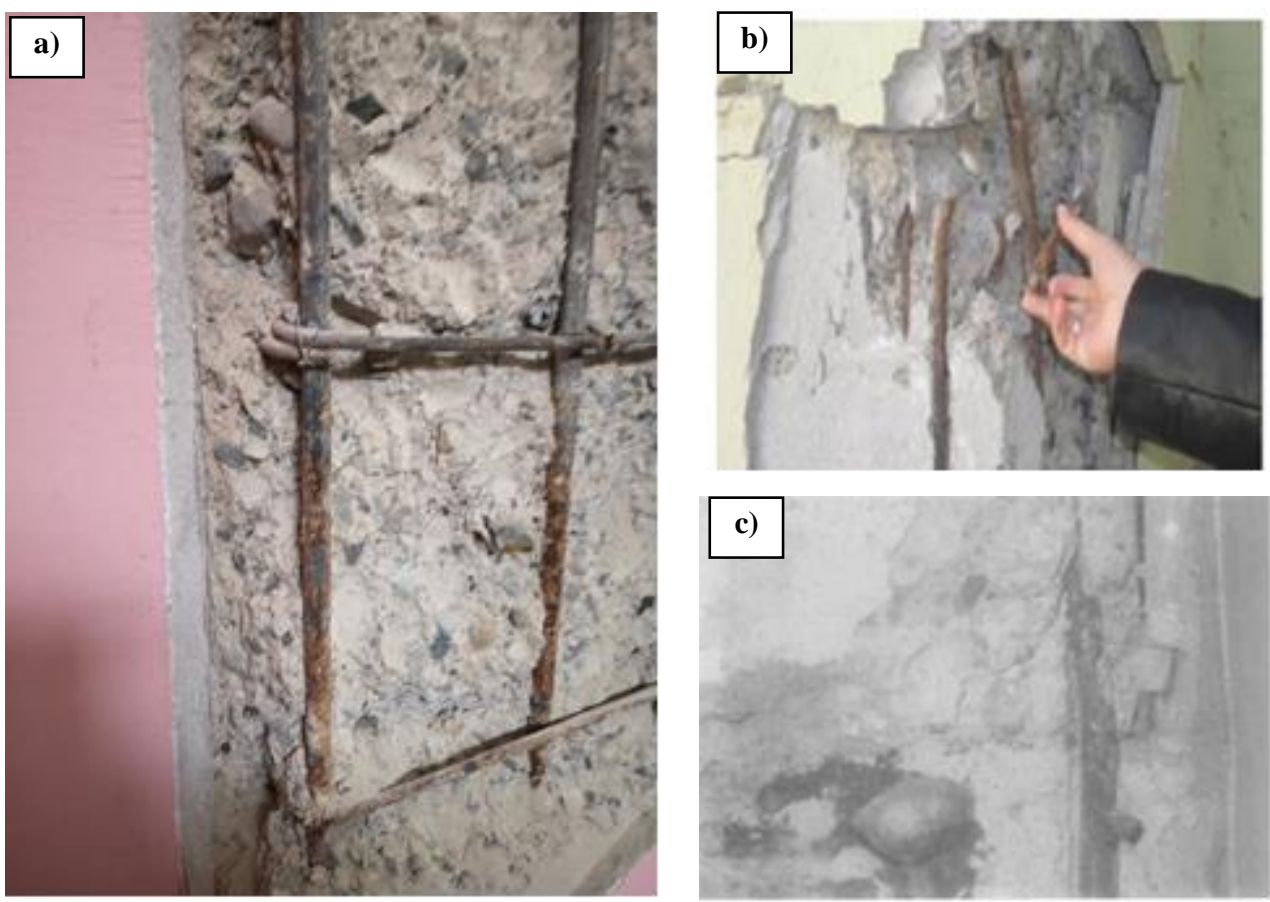

Fig. 14. The use of unribbed reinforcing bar and corrosion problems observed after (a) Elazığ-Sivrice, (b) Van [19] and (c) Bingöl [15] earthquakes 

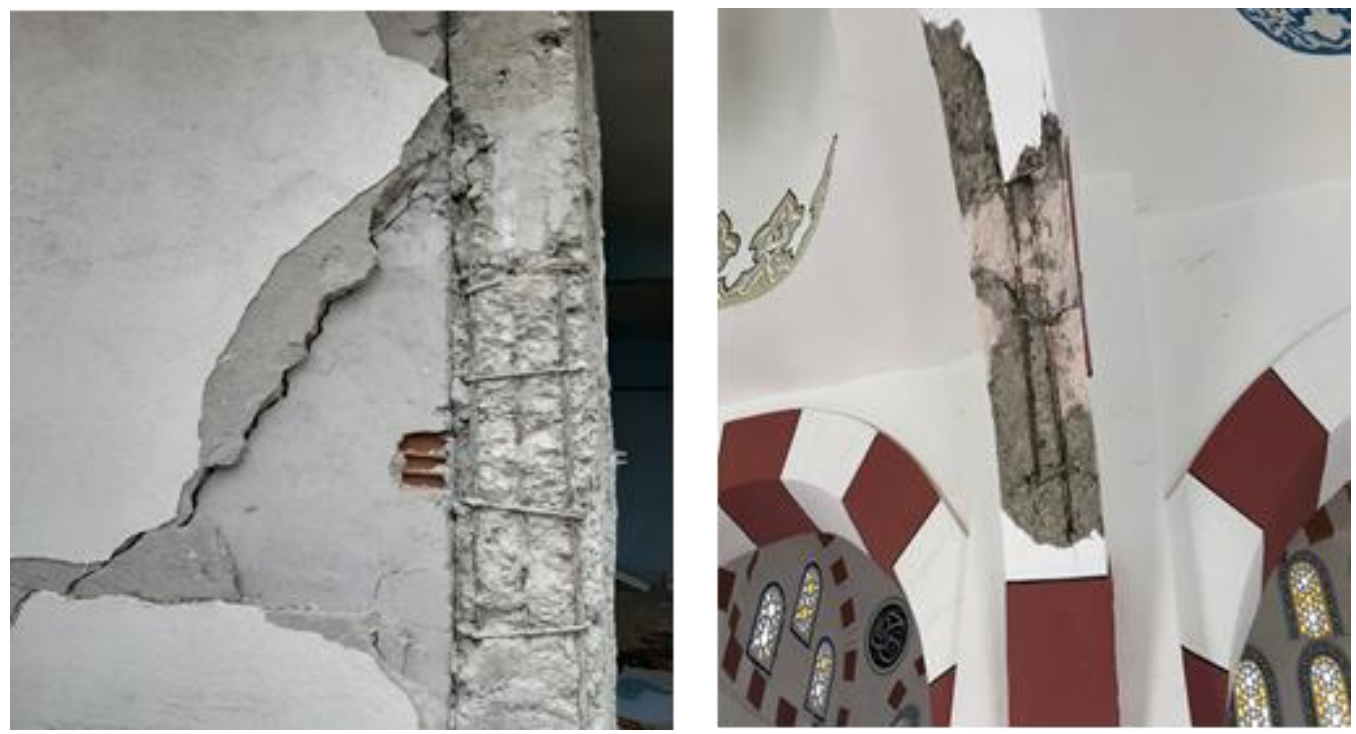

Fig. 15. Incorrect placing of reinforcement bars observed after Elazığ-Sivrice earthquake
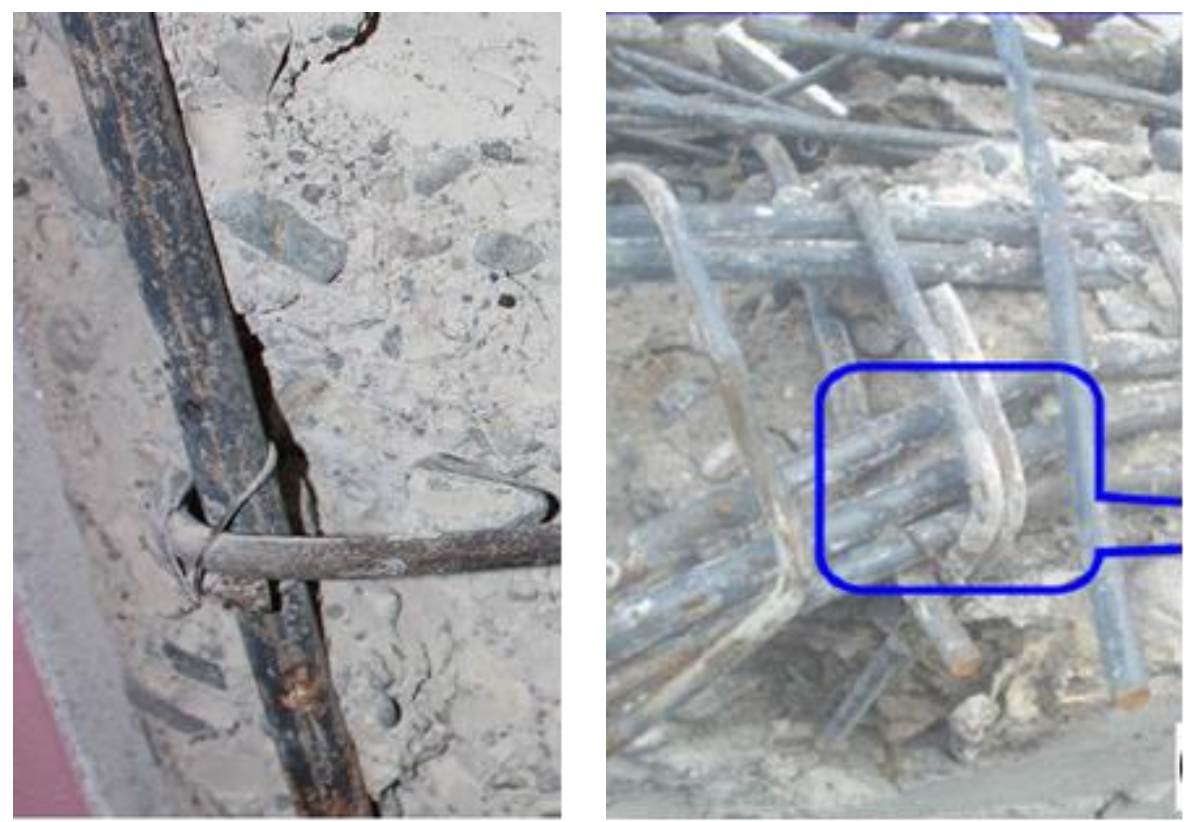

Fig. 16. Incorrect end hook angle and length observed after (a) Elazığ-Sivrice and (b) Van [31] earthquakes

\subsubsection{Weak gable walls}

Roof floors of some RC buildings are generally closed gamble walls constructed with some kind of brick or briquette. When these walls are not confined sufficiently, they fall down during an earthquake and cause loss of life and property (Fig.
17). TEC (1968, 1975, 1998 and 2007) stipulate that if the height of the gable walls resting on the horizontal bond beam at the top storey exceeds the $2.0 \mathrm{~m}$, vertical and inclined bond beams should be constructed. The height limit $(2.0 \mathrm{~m})$ is updated to be $0.80 \mathrm{~m}$ in TBEC (2018). 

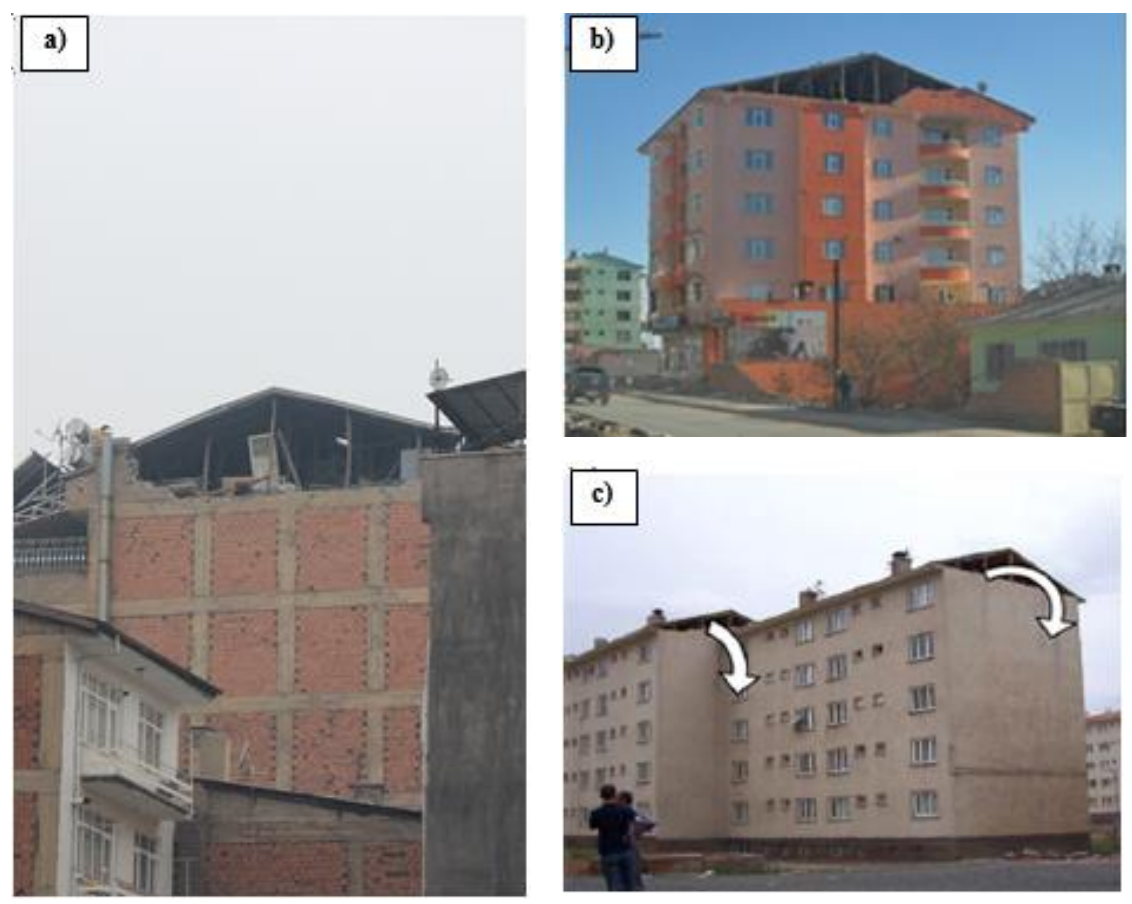

Fig. 17. Weak gable wall damages observed after

(a) Elazığ-Sivrice (b) Van [19] and (c) Bingöl [14] earthquakes

\subsubsection{Workmanship defects}

The design of RC buildings is as important as the process of the construction made by workmen. Although the building has an accurate design, the performance of the building depends on attention and care during construction. Observed workmanship defects in damaged or collapsed reinforced concrete buildings in past earthquakes are shown in Fig. 18.

\subsection{Damage to Masonry Buildings}

Masonry is one of the oldest construction technology still used to build many engineering structures around the world because of easy construction by using local material, good thermal properties in both cold and warm season, fire resistance, longer life span and high compressive strength. Masonry structures generally designed in order to withstand the vertical loads so they show good performance under this type of loads. However, under the horizontal loads such as earthquakes or wind, the performance of masonry sometimes is not good especially when constructed without satisfying requirements of earthquake codes.

Structural material used in walls, roofs and slabs of masonry buildings changes according to construction territory. A significant part of the building stock in Turkey is constituted of different type's masonry buildings, especially in rural areas. Masonry buildings divided mainly four groups according to material used in bearing wall such as stone masonry, adobe masonry, brick or briquette masonry, and half timbered masonry [32]. The selection of types of masonry buildings depends on the presence of the material to be used and experienced local craftsmen. For example, the usage of wood and stone is very high in the northern part of Turkey because in this part large forest areas where tree species are used in buildings and stone materials with high resistance to external effects are available. However, stone or adobe which is a mixture of soil, water, and some organic materials was used in the construction of masonry structures due to the scarcity of woodlands in the eastern region of Turkey. 

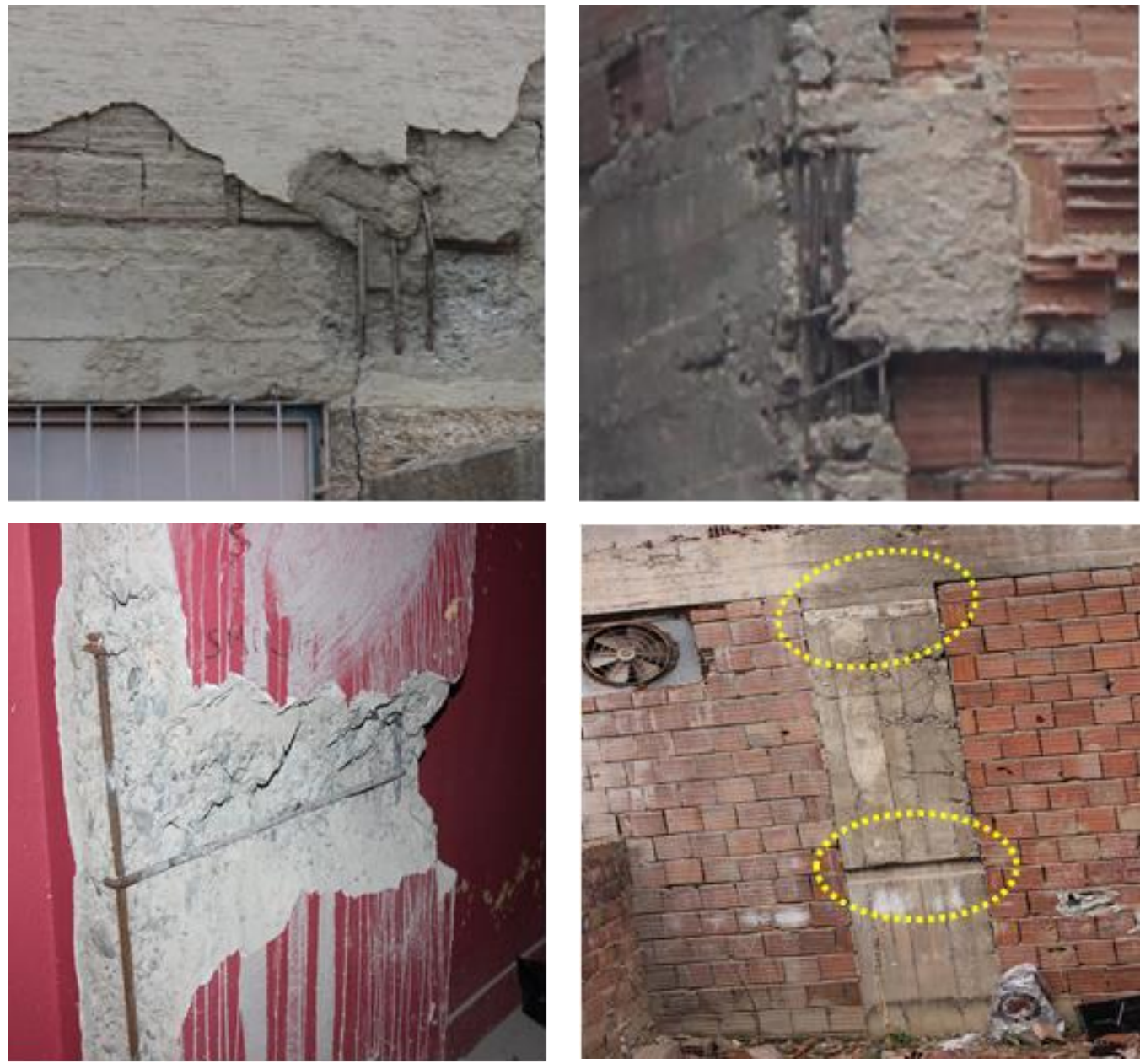

Fig. 18. Workmanship defects observed after Elazığ-Sivrice earthquake

The first recommendations about the construction of masonry structures were available in the TEC 1940. In the following years up to published date of the TEC 2018, comprehensive sections including material properties, dimensioning limits for walls and lintels, number of storey, foundation type, slab and roof section have been added to the earthquake codes. However, in rural areas, a significant part of the masonry structures built for shelter or livestock production are built by local craftsmen, according to their own experience, without engineering service. Therefore, masonry structures constructed in seismically active zones without taking into account the code rules are very fragile against to earthquakes. Past earthquakes that occurred in the last decades in Turkey also showed that the structural performance of masonry buildings was not good and caused many property and life losses. Previous reports and 24 January 2020 Elazığ-Sivrice earthquake field observations indicated that the poor quality of construction, inadequate material properties, heavy earth roofs and weak gable walls are general reasons for insufficient dynamic performance of masonry buildings.

\subsubsection{Poor construction quality}

The significant portion of masonry buildings are constructed by local craftsmen in the rural regions with their own experience without any engineering knowledge. It causes significant technical deficiencies in such buildings. Although these deficiencies do not cause damage under vertical loads, they cause heavy damage to buildings during 
horizontal loads such as earthquakes (Fig. 19 (a1)(b1)). The performance of masonry structures, especially under horizontal loads, depends on the integrity of structural elements such as walls, slab and roof as a whole. In order to ensure the integrity of the structure, connection between inside and outside walls and between walls and floors or roofs should be well designed (Fig. 19-(a2) and (b2)). Also according to the Turkish Earthquake Codes of 1968, 1975, 1998, 2007 and 2018, RC horizontal bond beam should be practiced at places where slabs are supported by walls to provide integrity of structural elements. Previous reports and 24

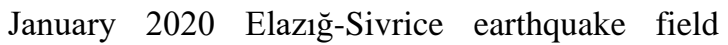
observations indicated that a concrete horizontal bond beam was almost no practiced in the damaged or collapsed masonry buildings.

Some masonry walls consist of two leaves such as inner and outer leaves. Proper big stones generally used to construct the outer layer, whereas smaller waste stones were filled inner layer without enough binding material. Therefore the connection of the inner and outer layer is not sufficient. This situation causes the leaves to form the wall not work together during the earthquake and may cause the wall to collapse (Fig. 19 (a3) and (b3)). The improper positioning of windows or door opening is another main reason caused damages of masonry buildings. The earthquake code of Turkey limits the distance between the corner of the wall and opening, also the distance between two openings. Also, the unsupported wall length of the loadbearing wall is limited according to the TEC 2018. Past reports and 24 January 2020 Elazı̆g-Sivrice earthquake field observations indicated that limits mentioned above did not apply to masonry buildings collapsed or damaged (Fig. 19 (a4) and (b4)). The other reason of damage or collapse of masonry building is using of different materials together in the construction of masonry walls such as stone and adobe, stone and brick, brick and adobe. When different materials types are used in wall causes improper distribution of strength and rigidity through the wall. In this case, sharing of lateral loads problems, and torsional moments can take place in walls (Fig. 19 (a5) and (b5)).

\subsubsection{Inadequate material properties}

Masonry structures transmit most of the horizontal and vertical loads to the foundation through their load-bearing walls. The strength of the wall is directly related to the strength of the materials that make up the wall. According to the TEC 1998, natural stone, solid brick or bricks with vertical holes are used for the construction of the wall and the compressive strength of these materials cannot be lower than $50 \mathrm{~kg} / \mathrm{cm} 2$. Also the shape of the natural stone is very important to ensure enough adherences between stones and mortar. Not proper shaped stones (smooth, round and irregular shape) cause low adherences. Natural stones should be used after shaped them into the proper shape and dimension. Insufficient binder property between stones or bricks is another reason to cause damage and collapse of masonry buildings. The lime mortar supported with cement or cement mortar should be used in walls as a binder material. But, due to the economical reason, mud mortar is generally used between stones and bricks (Fig. 20).

\subsubsection{Heavy earth roofs}

Traditionally, the roofs of masonry building in some rural region are covered with earth over the wooden locks to prevent water leakage and for heat isolation in both cold and hot season. The thickness of these roofs sometimes reaches to $1.0 \mathrm{~m}$. Thus, the weight of the structure increases, causing the additional lateral forces that affects the structure during the earthquake (Fig. 21).

\subsubsection{Weak gable walls}

The roof floor of some masonry buildings are generaly closed with gable walls constructed by using some kind of brick or briguette. When these walls are not confined sufficiently, they fall down during an earthquake and cause loss of life and property (Fig. 22). 

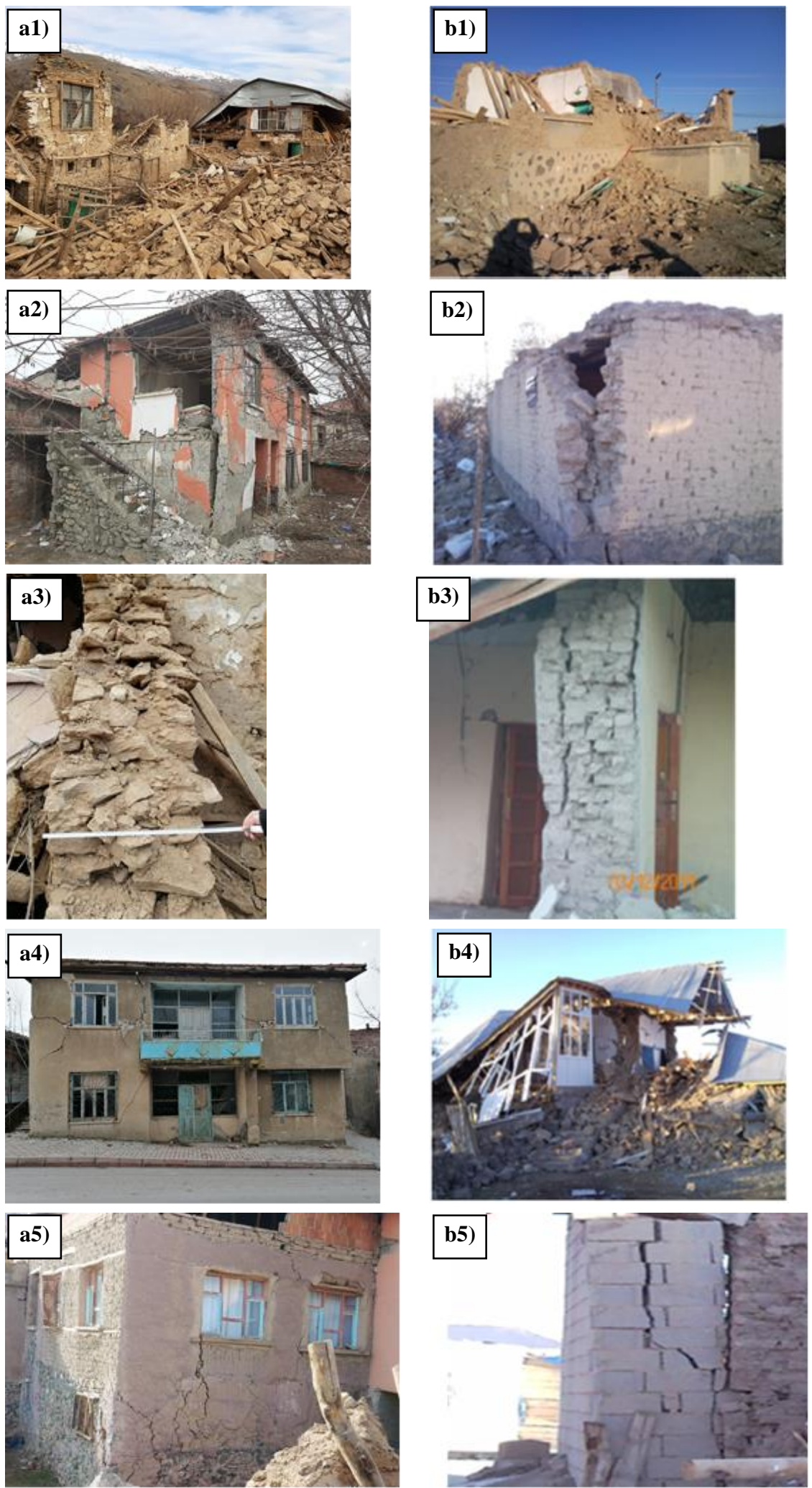

Fig. 19. The poor quality of construction damages observed after (a) Elazığ-Sivrice, and (b) Van [33] earthquakes 

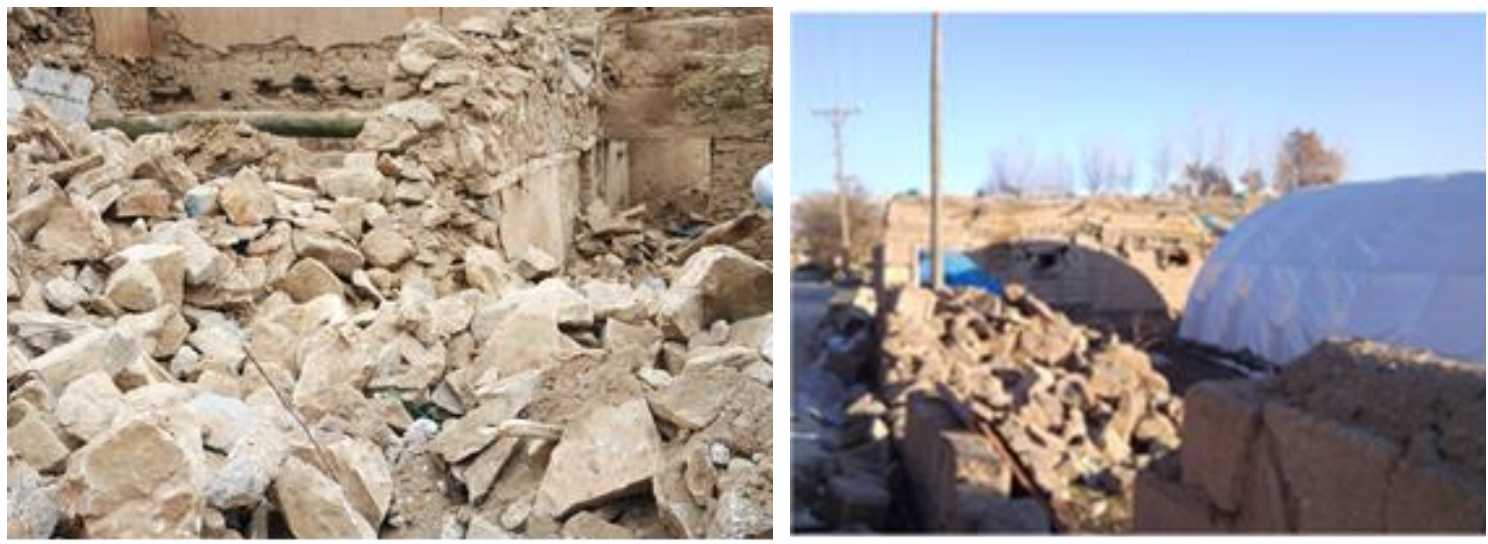

Fig. 20. Inadequate material properties damages observed after (a) Elazığ-Sivrice, and (b) Van [33] earthquakes
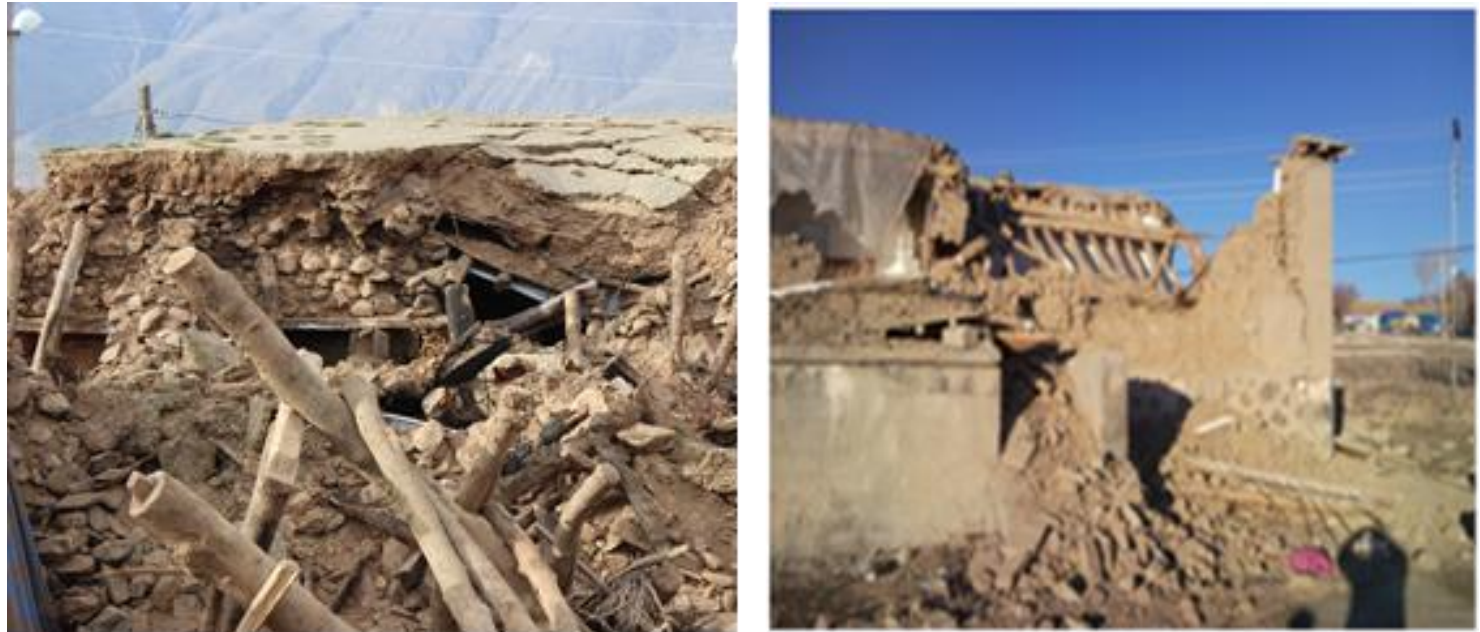

Fig. 21. Heavy earth roofs damages observed after (a) Elazığ-Sivrice, and (b) Van [33] earthquakes
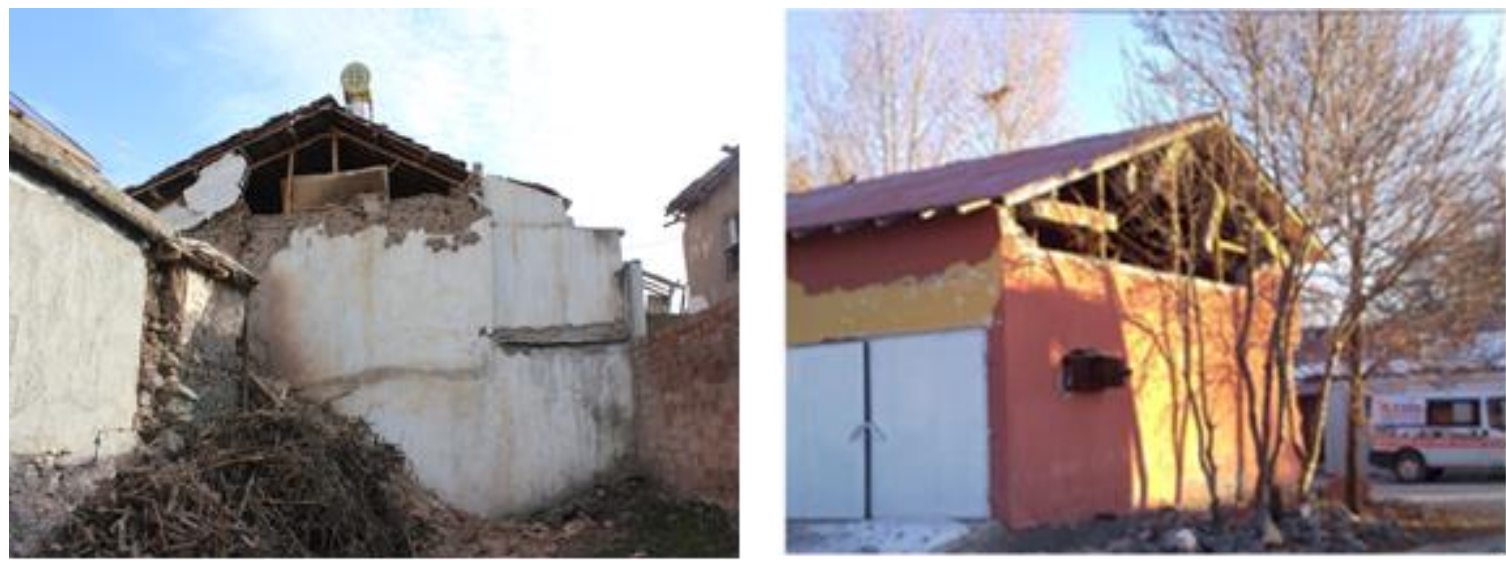

Fig. 22. Weak gable walls damages observed after (a) Elazığ-Sivrice, and (b) Van [33] earthquakes 


\section{Conclusions}

The performance of engineering structures exposed to earthquake can be determined better during earthquakes than analytical studies or laboratory tests. Because after the earthquakes, the behavior of different types of structures, damage patterns on structural elements, collapse mechanism and soil response etc. can be easily observed. For this reason, experiences taken from the past earthquakes will be important guide in minimizing loss of life and property in the future earthquakes.

When looking into building stock in Turkey, it is observed that a large part of the housing stock consist of RC and masonry structural system in urban and rural areas, respectively. This paper aims to outline the performance of $\mathrm{RC}$ and masonry buildings during the six major catastrophic earthquakes occurred between 1992 and 2020 in various regions of Turkey. Following conclusions are reached at the end of the study:

- The rapid population growth and the acceleration of the migration from the village to city after the eighties caused an increase in the need for housing in urban areas. Unfortunately, RC buildings constructed to meet this need have shown to us by earthquakes they were design and constructed without satisfying requirements of earthquake codes and insufficient inspection mechanism.

- Weaknesses in RC buildings caused damage or collapse during past earthquakes can be grouped under two headings such as errors made during design or construction stages.

- Errors made during design stages of RC building can be listed as (i) improper selection of the structural system, (ii) irregularities, (iii) strong beam-weak column, (iv) short column, (v) insufficient transverse reinforcement, (vi) soft and weak storey, (vii) existence of short unconfined lap splices, (viii) incorrect end hook angle, (ix) weak walls, (x) hammering effect, (xi) column-beam connection failures, (x) inadequate safe distance.

- Errors made during construction stages of RC building can be listed as (i) poor concrete quality, (ii) unribbed reinforcing bar and corrosion, (iii) incorrect placing of reinforcement bar, (iv) incorrect end hook angle and length, (v) weak gable walls, (vi) workmanship defects.

- The significant part of masonry buildings are constructed by local craftsmen in the rural regions with their own experience without any engineering knowledge. It causes significant technical deficiencies in such buildings. Although these deficiencies do not cause damage under vertical loads, they cause heavy damage to buildings during horizontal loads such as earthquakes

- Past earthquakes indicated that the poor quality of construction, inadequate material properties, heavy earth roofs and weak gable walls are general reasons for insufficient dynamic performance of masonry buildings.

These obtained results show that the main reasons causing heavy damaged and collapse of the $\mathrm{RC}$ and masonry buildings are lack of enforcement of earthquake code requirements and control of construction stages of these buildings.

\section{Declaration of conflicting interests}

The author(s) declared no potential conflicts of interest with respect to the research, authorship, and/or publication of this article.

\section{References}

[1] Zhao B, Taucer F, Rosetto T (2009) Field investigation on the performance of building structures during the 12 May 2008 Wenchuan earthquake in China. Engineering Structures 31:1707-1723.

[2] Augenti N, Parisi F (2010) Learning from construction failures due to the 2009 L'Aquila, Italy, earthquake. Journal of Performance of Constructed Facilities ASCE 24(6):536-555.

[3] Penna A, Morandi P, Rota M, Manzini CF, Porto F, Magenes G (2014) Performance of masonry buildings during the Emilia 2012 earthquake. Bulletin of Earthquake Engineering 12:2255-2273.

[4] Sharma K, Deng L, Noguez CC (2016) Field investigation on the performance of building structures during the April 25, 2015, Gorkha 
earthquake in Nepal. Engineering Structures 121:61-74.

[5] Ruiz-Pinilla JG, Adam JM, Perez-Carcel R, Yuste J, Moragues JJ (2016) Learning from RC building structures damaged by the earthquake in Lorca, Spain, in 2011. Engineering Failure Analysis 68:76-86.

[6] Gautam D, Chaulagain H (2016) Structural performance and associated lessons to be learned from world earthquakes in Nepal after 25 April 2015 (MW 7.8) Gorkha earthquake. Engineering Failure Analysis 68:222-243.

[7] Alih SC, Vafaei M (2019) Performance of reinforced concrete buildings and wooden structures during the $2015 \mathrm{Mw}$ 6.0 Sabah earthquake in Malaysia Nepal. Engineering Failure Analysis 102:351-368.

[8] Bruneau M, Saatcioğlu M (1994) Behavior of unreinforced masonry structures during the 1992 Erzincan, Turkey, Earthquake. TMS Journal February: 79-87.

[9] Sucuoğlu H, Erberik A (1997) Performance evaluation of a three-storey unreinforced masonry building during the 1992 Erzincan earthquake. Earthquake Engineering and Structural Dynamics 26:319-336.

[10] Hassan AF, Sözen MA (1997) Seismic vulnerability assessment of low-rise buildings in region with infrequent earthquakes. ACI Structural Journal 94(1):31-39.

[11] Adalier K, Aydingun O (2001) Structural engineering aspects of the June 27, 1998 AdanaCeyhan (Turkey) earthquake. Engineering Structures 23:343-355.

[12] USGS. Implications for Earthquake Risk Reduction in the United States from the Kocaeli, Turkey, Earthquake of August 17, 1999. U.S. Geological Survey Circular 1193, p. 3. Denver, CO: U.S. Government Printing Office, 2000.

[13] Sezen H, Whittaker AS, Elwood KJ, Mosalam KM (2003) Performance of reinforced concrete buildings during the August 17, 1999 Kocaeli, Turkey earthquake, and seismic design and construction practice in Turkey. Engineering Structures 25:103-114.

[14] Doğangün A (2004) Performance of reinforced concrete buildings during the May 1, 2003 Bingöl Earthquake in Turkey. Engineering Structures 26:841-856.

[15] Kaplan H, Yılmaz, S, Binici H, Yazar E. Çetinkaya N (2004) May 1, 2003 Turkey Bingöl earthquake: damage in reinforced concrete structures. Engineering Failure Analysis 11:279-291.

[16] Çağatay İH (2005) Experimental evaluation of buildings damaged in recent earthquakes in Turkey. Engineering Failure Analysis 12:440-452.

[17] Arslan MH, Korkmaz HH (2007) What is to be learned from damage and failure of reinforced concrete structures during recent earthquakes in Turkey?. Engineering Failure Analysis 14:1-22.

[18] İlki A, Celep Z (2012) Earthquakes, existing buildings and seismic design codes in Turkey. Arabian Journal of Science and Engineering 37:365-380.

[19] Bayraktar A, Altunışık AC, Pehlivan M (2013) Performance and damages of reinforced concrete buildings during the October 23 and November 9, 2011 Van, Turkey, earthquakes. Soil Dynamics and Earthquake Engineering 53:49-72.

[20] Bayraktar A, Altunışık AC, Türker T, Karadeniz H, Erdoğdu Ş, Angın Z, Özşahin TŞ (2015) Structural performance evaluation of $90 \mathrm{RC}$ buildings collapsed during October 23 and November 9, 2011 Van, Turkey, earthquakes. Journal of Performance of Constructed Facilities ASCE 29(6):1-19.

[21] Ateş Ş, Kahya V, Yurdakul M, Adanur S (2013) Damages on reinforced concrete buildings due to consecutive earthquakes in Van. Soil Dynamics and Earthquake Engineering 53:109-118.

[22] AFAD (2020) Earthquake Department of the Disaster and Emergency Management Presidency, Ankara, Turkey. http://www.afad.gov.tr

[23] http://www.geo.mtu.edu/UPSeis/magnitude.html

[24] TEC (1940) Ministry of Public Works, Zelzele Mintıkaları Muvakkat Yapı Talimatnamesi (in Turkish).

[25] TEC (1968) Ministry of Public Works and Housing, Afet Bölgelerinde Yapılacak Yapılar Hakkında Yönetmelik (in Turkish).

[26] TEC (1975) Ministry of Public Works and Housing, Afet Bölgelerinde Yapılacak Yapılar Hakkında Yönetmelik (in Turkish).

[27] TEC (1998) Ministry of Public Works and Housing, Afet Bölgelerinde Yapılacak Yapılar Hakkında Yönetmelik (in Turkish).

[28] TEC (2007) Ministry of Public Works and Housing, Deprem Bölgelerinde Yapılacak Binalar Hakkında Esaslar, Disaster and Emergency Management Presidency, (in Turkish).

[29] TBEC (2018). Disaster and Emergency Management Presidency, Türkiye Bina Deprem Yönetmeliği (in Turkish). 
[30] AIJ/JSCE/BU Damage report on 1992 Erzincan earthquake, Turkey. Technical Report by Joint Reconnaissance Team of Architectural Institute of Japan, Japan Society of Civil Engineers, Boğaziçi University, Istanbul, 1993.

[31] Doğan M (2013) Failure of structural (RC, masonry, bridge) to Van earthquake. Engineering Failure Analysis 35:1489-498.
[32] Korkmaz HH, Korkmaz SZ, Donduren MS (2010) Earthquake hazard and damage on traditional rural structures in Turkey, Natural Hazards and Earth System Sciences 10:605-622.

[33] Bayraktar A, Altunışık AC, Muvafik M (2016) Field investigation of the performance of masonry buildings during the October 23 and November 9, 2011, Van Earthquakes in Turkey. Journal of Performance of Constructed Facilities 30(2):1-10. 